Bond University

Research Repository

\title{
Governing Behavioral Relationships in Megaprojects: Examining Effect of Three Governance Mechanisms under Project Uncertainties
}

Zheng, Xian; Lu, Yujie; Chang, Rui-dong

Published in:

Journal of Management in Engineering - ASCE

DOI:

10.1061/\%28ASCE\%29ME.1943-5479.0000701

Licence:

Other

Link to output in Bond University research repository.

Recommended citation(APA):

Zheng, X., Lu, Y., \& Chang, R. (2019). Governing Behavioral Relationships in Megaprojects: Examining Effect of Three Governance Mechanisms under Project Uncertainties. Journal of Management in Engineering - ASCE, 35(5). https://doi.org/10.1061/\%28ASCE\%29ME.1943-5479.0000701

\section{General rights}

Copyright and moral rights for the publications made accessible in the public portal are retained by the authors and/or other copyright owners and it is a condition of accessing publications that users recognise and abide by the legal requirements associated with these rights.

For more information, or if you believe that this document breaches copyright, please contact the Bond University research repository coordinator 
1 How to Govern Behavioral Relationship in Megaprojects? Examining the Effect of Three Governance Mechanisms under Project Uncertainties

$$
\text { Xian Zheng }{ }^{1} \text {, Yujie } \text { Lu }^{2 *} \text {, Ruidong Chang }{ }^{3}
$$

Abstract: The relational behavior of project participants is crucial to the success of a megaproject. Although project governance has been widely studied with the aim of improving participants' relational behavior, limited research examines the distinct effectiveness of various governance mechanisms on influencing relational behavior, especially in megaprojects. Through examining three varieties of governance mechanisms, including contract, trust and institutional support, a hierarchical moderated regression analysis has been used to explore the impact of each of the governance mechanisms in facilitating the relational behavior of megaproject participants and further team performance. The analysis is based on data collected from 202 contractors and consultants working at megaprojects in China. Results unveiled that both contractual term specificity and its interaction with trust can facilitate relational behavior. Project uncertainty moderates the relationship between governance mechanisms and relational behavior in affecting project team performance. The findings offer both theoretical and managerial implications for megaproject participants to cultivate beneficial relational behavior so as to improve team performance in megaprojects.

Keywords: Contractual governance, Governance mechanisms, Institutional support,

\footnotetext{
${ }^{1}$ Lecturer, Department of investment, School of Finance, Zhongnan University of Economics and Law, China 430073. Email: sine2588@163.com.

2 *(Corresponding author) Department of Building Engineering, College of Civil Engineering, 1239 Siping Road, Tongji University, China 200092; Key Laboratory of Performance Evolution and Control for Engineering Structures of Ministry of Education, Tongji University, China 200092. Email: lu6@tongji.edu.cn

${ }^{3}$ Assistant Professor, Centre for Comparative Construction Research, Faculty of Society and Design, Bond University, Australia 4226. E-mail: rchang@bond.edu.au.
} 
Megaprojects, Relational behavior, Trust

\section{INTRODUCTION}

Relational behavior has been receiving considerable attentions as one of the approaches to realize high-quality inter-organizational relationships in construction projects (Ning and Ling 2014). Relational behavior refers to the desired actions involved in the exchange that promote the development of a collaborative relationship. Three most commonly observed relational behaviors are those pertaining to flexibility, information exchange and solidarity (Heide and John 1992; Hewett and Bearden 2001; Lusch and Brown 1996). Specifically, flexibility refers to the shared expectations between the partners regarding the way they will behave when unanticipated changes in the contractual environment occur; information exchange is the shared expectation that information will be continually and freely exchanged; and solidarity is defined as the shared expectation that each partner will behave in a manner that benefits the collaboration as a whole rather than simply protecting their own interests (Heide and John 1992).

Such behaviors have been proved to be critical to foster and maintain a value-enhancing relationship among organizations and to enhance their performance (Griffith et al. 2006). This is especially true for successful megaprojects, such as the Thames Barrier and the Heysham 2 Nuclear Power Station, in which project organizations tend to involve active relational behavior and high relationship quality between one another (Morris and Hough 1987). The reason is that megaprojects are expected to accomplish a challenging goal that cannot be completed by individual party alone, thereby calling for multiple stakeholders to conduct intensive relational behavior so as to achieve the success of projects (Zheng et al. 2017).

Dyer and Singh (1998) pointed out that governance "plays a key role" in the creation of 
41 inter-organizational relationship because it influences transaction costs and the willingness of partners to engage in value-creation initiatives. In the construction field, a project created by contracts could be regarded as a temporary coalition of firms working collectively with clients (Winch 1989). A project's temporary, uniqueness, heterogeneous, short-term orientation and lack of organizational routines pose special challenges to stakeholders' relationship management (Hanisch and Wald 2011). For instance, the collaboration in the coalition could be difficult (Phelps and Reddy 2009) and opportunism often occurs (Lau and Rowlinson 2009; Lu et al. 2016). Thus, effective governance that is able to develop a trustworthy relationship and implement relational behaviors among project participants is pivotal to the success of construction projects.

The literature has suggested that two main types of governance are at play in an interorganizational relationship, namely contractual governance and relational governance (Heide 1994; Jap and Anderson 2003; Poppo and Zenger 2002). Contractual governance refers to mechanisms that to govern interparty exchanges and to avoid uncertainties through emphasizing the importance of the contracts between transaction partners (Lumineau et al. 2011). The role of contractual governance has been greatly emphasized by transaction cost economics in explicit terms and conditions (Cannon et al. 2000). Relational governance emphasizes inherent and moral control mechanisms, which are used to govern exchanges through consistent goals and a cooperative atmosphere (Lu et al. 2015). Relational governance such as trust is based on the relational exchange theory, which offers a less explicit set of terms to maintain a value-enhancing relationship (Macneil 1980).

The effectiveness of contracts and trust in governing inter-organizational behavior and their 
effects on cooperation performances have been widely studied (Luo 2002; Yang et al. 2011). In megaprojects, there are many endogenous factors driving relation conflicts such as ambiguous contracts, opportunistic behaviors, differences in goals and operational routines, and unexpected market changes (Jap and Ganesan 2000). Most importantly, megaprojects are largescale sociotechnical undertakings that cost over 1 Billion RMB (Chinese Currency) and that are complex and embedded in institutional frames (He et al. 2015). These project incorporated both traditional infrastructure such as transportation megaprojects but also large-scale public projects such as National Stadium for the 2008 Olympics and 2010 Shanghai World Expo projects, providing fundamental public services for economic development, social production, and people's life (Flyvbjerg 2011). Thus, Flyvbjerg (2014) argued that megaprojects are a completely different breed of projects and have to be managed differently from conventional projects. Prominent project management scholars have advocated that high attention needs to be paid to the institutional environment in which megaprojects are situated, especially in transition economies such as China (Chi et al. 2011), where the centralized political structure is implemented and dominated by the government both financially and administratively. The government who initiates a megaproject usually acts as both a regulator and a client. For instance, the government in China, as a regulator, often relied on administrative powers and means to govern megaprojects ( $\mathrm{Li}$ et al. 2018). This is attributed to China's institutional systems which are characterized by centralization governance and elitist governance. In addition, the client's role of government is operationalized through the central role of the Construction Headquarters - a project-specific organization set up by the government for managing the megaproject (Zhai et al. 2017). Thus, in this study, the institutional support is regarded as a 
governance mechanism to influence relational behavior in megaprojects.

Given limited studies on the governance of relational behavior in megaprojects, three research gaps can be identified as follows. First, extant research regards the contract mechanism as an individual construct, but ignores different functions of the contract, e.g. specificity and adaptability, that might have a district effect on relational behaviors. Second, previous research primarily focuses on contractual governance and relationship governance, but seldom highlights the government's institutional support to influence relational behavior in megaprojects. Third, limited research has focused on the megaproject's uncertainties that influence the effect of governance mechanisms on relational behavior. To fill these gaps, this study empirically examines the effectiveness of various governance mechanisms on relational behavior among participating organizations under different levels of megaproject uncertainties in transition economies.

Specifically, the three objectives of this study are: (1) to examine two different roles of contractual governance mechanisms (i.e. contractual term specificity and contractual contingency adaptability) on relational behavior in megaprojects; (2) to investigate the effect of trust and institutional support on relational behavior; and (3) to investigate the moderating effect of project uncertainty in influencing distinct governance mechanisms. These issues were examined using survey data from 202 contractors and consultants of megaprojects in China. The results could be helpful to strategize the relationship management and to further improve team performance.

The remainder of this paper is organized as follows. In the following section, we proposed the research hypotheses, followed by the next section where the research method for data 
collection and analysis is provided. We then discussed the findings and their managerial implications, and concluded the study with limitations and suggestions for future research.

\section{LITERATURE REVIEW}

\section{Relational Behavior}

The concept of relational behavior is drawn from the relational exchange norms framework proposed by Macneil (1980) that identified 28 overlapping relational exchange norms, each of which refers to a set of shared expectations regarding a particular type of exchange behavior that reflects the parties' mutuality of interests and a common long-term orientation (Sezen and Yilmaz 2007). This concept was developed further by Heide and John (1992), who proposed that the three most commonly observed relational behaviors are those pertaining to the norms of flexibility, information exchange, and solidarity. This conjecture has now been supported by a variety of reports in the literature (Hoppner and Griffith 2011; Ni et al. 2017) and was thus selected as the component of relational behavior for this study.

The extant literature on relational behavior in the construction industry has, for the most part, concentrated on its drivers, hindrances, measure, and consequences (Memon 2014; Che et al. 2015). Regarding its drivers, the effectiveness of contracts and trust in governing interorganizational relationship and their effects on relational behavior have been studied respectively. For example, Ning et al. (2013) suggested that trust is among one of the most significant promoters of relational behavior, while Ke et al. (2013) examined the effects of various relational behaviors on relationship quality and project outcomes under different contract strategies. However, systematic analysis on the effect of governance mechanisms to relational behavior is scarce in the field of construction, especially in the context of the 
megaproject.

Compared with ordinary projects, both the frequency of interactions and the level of uncertainty are high in megaprojects from the perspective of transaction costs economics. Besides, the outcome of megaprojects is unpredictable, which indicate it is difficult to specify the contractual terms and clauses in advance (Park et al. 2017). These facts may mean that trust and the role of government are more important than contracts to facilitate relational behavior in megaprojects, especially in China — a country rich with guanxi. Li et al. (2018) highlighted that megaproject governance includes mandatory approaches such as formal policies, regulations, and programs, as well as informal project culture and relationship governance. Take World Explo 2010 in China as an example, the government support, such as the appointment of top management teams, the establishment of "project-oriented state-owned enterprises," and the relations between government and private entities have great effect on the project performance. Therefore, it is essential to test the effect of various governance mechanisms on relational behavior in the context of megaproject settings.

\section{Governance Mechanisms in Megaprojects}

Governance mechanisms are safeguards that firms put in place to regulate inter-firm exchange, minimize exposure to opportunism, protect transaction cost investment, and promote the continuance of relationships (Jap and Ganesan 2000). It incorporates the formal and informal rules of exchange between partners, such as incentive structures, monitoring mechanisms, contractual provisions, reputations, norms, and trust (Jap and Anderson 2003). The literature has suggested that two main types of governance for inter-organizational relationships, namely the formal governance mechanism and informal governance mechanism 
151 (Cao and Lumineau 2015). The theoretical category used in the main studies to summarize the 152 interplay of formal and informal governance is demonstrated in Table 1.

As shown in Table 1, contractual governance and trust are two main types suggested by the previous literature. Contractual governance refers to the extent to which an interorganizational relationship is governed by a formal and written contract that explicitly stipulates

157 the responsibilities and obligations of each party (Williamson 1985). By specifying each party's

158 rights and duties, contractual governance may reduce opportunism and safeguard an inter-

159 organizational relationship (Williamson 1985). Contractual governance plays an important role

160 in reducing risks and facilitating coordination when megaproject participants conduct relational

161 behavior (Malhotra and Lumineau 2011; Schepker et al. 2014). However, the majority of

162 previous studies viewed contractual governance as an uni-dimensional construct (i.e., clause

163 specificity), and caused a debate upon whether contracts should be more specific. Extended

164 from this, contractual governance has been further defined as a two-dimensional construct that

165 includes both the extent to which contractual terms are clearly specified (i.e., contractual term

166 specificity), and the possible contingencies that a contract accounts for (i.e., contractual

167 contingency adaptability) (Luo 2002). These two dimensions capture different aspects of

168 contract completeness in which a transaction necessitates high contractual term specificity to

169 restrain opportunism and also requires descriptions of contingencies that foster adaptation when

170 unexpected events occur. Drawing on the multidimensional aspect of contracts, this study

171 intended to investigate the effect of these two contract dimensions on relational behavior in megaprojects. 
In addition to formal contracts, Trust is one of the most significant relational governance

174 or informal influence since in a megaproject, the government could act as both a regulator and mechanisms which is proposed based on the relational exchange theory to maintain valueenhancing relationship. A higher level of relational governance mechanism application in megaprojects indicates more informal interaction among stakeholders and less focus on formal contracts, thus contributing to organizational mutual adaptability and self-enforcing safeguard against conflicts and commitment-level relationship (Xue et al. 2016). Seen from Table 1, institutional support from the government has also been regarded as a significant relational mechanism in emerging economies like China (Chi et al. 2011). Institutional support is determined by the institutional environment of a country or a state. Emerging economies are commonly characterized by extensive government involvement and intervention in economic exchanges and market transactions (Davies and Walters 2004; Hellman and Schankerman 2000). Researchers have suggested the importance of aligning project governance with projects' surrounding institutions to facilitate project success (Ahola et al. 2014). Institutional support from the central or local governments can support relational behavior among parties. Moreover, a bonding and commitment rested on a relationship can help overcome turbulences in the course of projects (Henisz et al. 2012). In a real-world situation, several safeguarding measures will be employed in combination.

In addition to a contract as a frequently employed formal mechanism and trust being a typical informal mechanism, several other mechanisms, such as institutional support from the government are the third category. Those mechanisms can be categorized to either the formal

194 a client to reflect both its administrative powers and informal actions. In this study, those 
195

mechanisms are referred as institutional support (by the government) and it highlights the significant role of government in megaprojects. Thus, three main types of governance mechanisms for inter-organizational relationships, namely the contract, trust and institutional support, were identified to examine their effects on relational behavior in megaprojects.

Although an increasing number of studies evaluated the effect of several safeguards to enhance relationship performance (Osipova 2015), few studies examined the dependent nature of contracts, trust, and institutional support on influencing relational behavior in the context of a megaproject which is situated in a wide socio-political environment and is subject to a high level of uncertainty. relationship performance (Osipova 2015), few studies examined the dependent nature of contracts, trust, and institutional support on relational behavior in the context of a megaproject which is often subject to the impacts of a wider socio-political environment and is subject to a high level of uncertainty. For collaboration among multiple megaproject participants, project uncertainty cannot be ignored as the effect of governance mechanisms on participants' relational behavior may vary under various levels of project uncertainty. Consequently, there is a need for empirical research to determine the effect of the simultaneous use of multiple governance mechanisms on relational behavior under different megaproject context.

\section{HYPOTHESIS DEVELOPMENT}

\section{Governance Mechanisms and Relational Behavior}

As one of the main component of contractual governance mechanism, contractual term specificity refers to the extent to which contractual terms are clearly specified. It may reinforce the relational behavior of megaproject participants through three mechanisms. First, Myers 
217 (2007) suggested that contractual term specificity protects a partner's strategic resources and

218 reduces operational and financial uncertainties by controlling opportunism and spurring

219 information flow. Using appropriate contractual safeguards to reduce opportunism and preserve

220 relationships is of paramount importance in megaprojects that typically involve long duration

221 and the commitment of idiosyncratic assets (Ke et al. 2013). Thus, both decreased opportunism

222 and increased relationship are beneficial for cultivating the relational behavior of megaproject

223 participants. Second, contractual specificity can help project participants to exchange their

224 understanding, expectations, and respective roles in the transaction (Beatty and Samuelson

225 1990) and to mitigate the risk of misunderstandings that will disrupt collaboration among

226 (presumably) well-intentioned parties (Malhotra and Lumineau 2011). Thus, specific contracts

227 could facilitate the formation of relational behavior among participants with reduced risks,

228 potential conflicts and disputes (Zhang et al. 2016). Third, when clients explicitly specify the

229 performance outcome, they expect the service supplier to deliver (Das and Teng 2001;

230 Eisenhardt 1985). It aligns with the preferences and goals of all contracting parties. With a

231 substantial reduction in incongruent self-interests, contractual term specificity may further

232 enhance participants' relational behavior.

233 Contractual contingency adaptability is the extent to which unanticipated contingencies

234 are accounted for and relevant guidelines that are delineated in a contract for handling these

235 contingencies (Luo 2002). It stipulates principles, guidelines, and possible solutions for dealing

236 with conflicts and contingencies, outlining a mutually agreed tolerance zone or excuse doctrine

237 for dealing with unexpected events. In practice, these guidelines or possible solutions are

238 incorporated in a contract as independent terms (e.g., procedures for handling important 
contingencies, guidelines in case of doubt or hazards, approaches for overcoming conflict and handling force majeure) or as a part of relevant clauses in specific cases (e.g., how to handle unanticipated changes in the market or governmental policies). With contractual contingency adaptability, a contract is expected to foster flexibility by furnishing customized approaches and contingency procedures for dealing with future contingencies, especially in megaprojects with great uncertainties, as contracting parties know that the contract is not perfectly rigid and will evolve as needs change, calling for the processes that can accommodate such changes. For instance, a demand forecast plan or business continuity plan may contain provisions that entail contingency plans for the relationship. These provisions reflect the joint expectation that megaproject participants are willing to make necessary adaptations to the contract as business and environmental circumstances change (Dwyer et al. 1987). Contractual contingency adaptability is important and especially conducive to promote inter-organizational relational behavior (Doz 1996) when a conflict arises. Otherwise, disputing participants are unlikely to further engage in effective communication (Hinds and Mortensen 2005). Therefore, this study proposes the following two hypotheses firstly:

Hypothesis 1a (H1a): Contractual term specificity in a contract has a positive effect on the relational behavior of megaproject participants.

Hypothesis $1 \mathrm{~b}(\mathrm{H} 1 \mathrm{~b})$ : Contractual contingency adaptability in a contract has a positive effect on the relational behavior of megaproject participants.

Rather than contractual governance that relies on formal agreements with third-party enforcement, relational governance relies on informal structure and self-enforcement by each party (Dyer and Singh 1998; Malhotra and Murnighan 2002). In the existing literature, trust is 
261

one of the most frequently discussed forms of relational governance (Griffith and Myers 2005). In relational exchange theory, trust relates positively to relational behavior because confidence in and reliance on the other partners promote their mutual flexibility, solidarity, and information exchange (Lui et al. 2009). Poppo and Zenger (2002) proposed that trust not only enhances mutual adaptability and facilitates joint planning (Claro et al. 2003) but also contributes to a commitment-level relationship that operates as a self-enforcing safeguard against conflicts (Malhotra and Lumineau 2011).

In megaprojects where many conflicts, differences, disputes, and other undesirable behaviors exist with a high level of trust, participants reduce the cost of monitoring, controlling, and enforcing (Goo et al. 2009) and increase the possibility to attain mutually beneficial agreements (Khalfan et al. 2007), eventually improving project performance (Jiang et al. 2016; Meng 2012). Pinto et al. (2009) found that trust helps to strengthen cooperation, which, in turn, benefits the project as a whole.

In China, the role of trust may be even more salient (Möller and Svahn 2004). The lack of a robust regulatory institution compels firms to rely more on social connections and trust to obtain needed resources and protection (Jiang and Lu 2017; Memon et al. 2014). Business conducted in China also has the tradition of heavily relying on informal ties with trustworthy partners. As Xin and Pearce (1996) pointed out, trust and credibility are more instrumental than a legal framework in guiding business cooperation in China. Chinese project managers prefer to develop and maintain a good, even personal, relationship with their clients (Chen and Partington 2004), which is an essential attribute of good project management. As a result, good relationships with all involved parties are vital for resolving conflicts, facilitating 
communication, and sharing knowledge (Rahman and Alhassan 2012). Thus, the following hypothesis was proposed:

Hypothesis 2 (H2): Trust has a positive effect on the relational behavior of megaproject participants.

Institutional support from the central or local government is another governance mechanism that incorporates the availability of valuable industry information, subsidies, tax reductions, and regulatory favors (Pistor et al. 2000). Due to these potential benefits, megaproject participants would seek increased political networking with the government to build a close relationship in the expectation of higher chances to win future contracts. Chi and Javernick - Will (2011) proposed that political networking generates greater value when located in certain strategic or hierarchical positions where useful information about opportunities is available, with power derived from decision-making authority or access to valued resources. In megaprojects, the government can also be understood as an intermediary that combines its own legal stake and society's moral stake (Sallinen et al. 2013). The government was actively promoting a shared view of the societal importance of the megaproject to affirm the commitment of megaproject participants, thus facilitating their relational behavior. In China, the use of this governance approach has earlier been demonstrated with linkage to relational norms of national glory and individual values (Chi et al. 2011), and with the potential to promote relational behavior among megaproject participants. The following hypothesis was proposed:

Hypothesis 3 (H3): Institutional support has a positive effect on the relational behavior of megaproject participants. 


\section{Interaction of Governance Mechanisms}

As to the relationship between contractual and relational governance, two viewpoints arise

307 in the existing literature. Some scholars suggested that these two governance mechanisms can complement each other's inadequacies and limitations in achieving higher exchange performance and in constraining opportunism (Lui et al. 2009; Poppo and Zenger 2002). However, others have viewed the relational mechanism as a substitute for a complex and

311 explicit contract (Cao and Lumineau 2015). Recent studies have provided more nuanced

312 explanations of the mutual relationship between contractual and relational governance. They

313 argued that both complementary and substitute propositions are possible, depending on the contents and functions of contracts as well as contextual factors (Hinds and Mortensen 2005).

315 In particular, recent works indicate that multiple dimensions of contractual governance may

316 have different impacts on relational governance (Malhotra and Lumineau 2011; Schepker et al. 317 2014).

In terms of contractual term specificity, regardless of how explicit a contract is, the

319 interpretation and application of contracts may be different between cooperative parties. Some

320 firms use contractual terms rigidly while other firms use the terms in a more flexible way.

321 Different applications may generate conflicts and degrade cooperation. As such, project participants may turn to a relational mechanism such as trust (Williamson 1985) because the

323 continuity and cooperation encouraged by relational mechanisms may generate contractual

324 refinements and further support greater collaboration (Poppo and Zenger 2002). Trust is broadly considered as being flexible and adaptable, so it can overcome the adaptive limits of contractual term specificity and complement it by fostering continuance and bilateralism when change and 
conflict arise. From another perspective, trust is difficult to be formally codified as ambiguous expectations and misunderstandings will arise, which undermines coordination and even results in opportunism (Weitz and Jap 1995). Overcoming the informal limitations of trust, contractual term specificity can complement it through formal clauses that help establish a solid basis for the development of trust. Therefore, term specificity can provide a formal framework for a megaproject and trust can eliminate contract limitations; that is, they function as mutual complements instead of substitutes. Jointly using these two mechanisms can potentially improve relational behavior more than using them separately (Liu et al. 2009).

Regarding contractual contingency adaptability, due to humans' natural bounded rationality, it is impossible to write a complete contract that anticipates all possible contingencies and clarifies the appropriate actions of each party (Wuyts and Geyskens 2005). Project managers cannot predict and contractually resolve every future contingency and, therefore, request an "incomplete" contract that is less legally binding as it contains fewer clauses and/or the clauses are neither observable nor verifiable (Dooley and Ven 1999). However, a lack of specific clauses may also introduce ambiguity and leave space for opportunistic behavior (Luo 2002). Furthermore, a higher level of contractual contingency adaptability may signal a lack of trust, which may be detrimental for the cooperative interorganizational relationship (Poppo and Zenger 2002). The following hypotheses were therefore proposed:

Hypothesis 4a (H4a). Contractual term specificity and trust are complementary in promoting the relational behavior of megaproject participants.

Hypothesis $4 \mathrm{~b}(\mathrm{H} 4 \mathrm{~b})$. Contractual contingency adaptability and trust are substitutes in 
promoting the relational behavior of megaproject participants.

\section{Moderating Effect of Project Uncertainty}

Project uncertainty refers to the frequency of changes and the degree of instability during the project lifecycle (Wang et al. 2011). Pertinent studies suggest three main sources of project uncertainty in a megaproject: task uncertainty, technological novelty, and environmental uncertainty (Yan and Dooley 2013). Task uncertainty arises from a large number of components and/or a high level of differentiation and interdependencies between them (Dooley and Ven 1999). High task uncertainty causes equivocality and multiple or conflicting interpretations of task situations (Koufteros et al. 2002). High uncertainty also requires highly differentiated expertise, making the integration of knowledge and skills very difficult. During the development of a megaproject, the complex interdependences among components make it challenging to predict and understand the impacts of distributed decisions on the overall task performance. As a result, megaprojects often take a longer time to complete. In addition, technological novelty is another source of megaproject uncertainty, and it varies at different levels (Tatikonda and Montoya-Weiss 2001). Novel technologies refer to those that are new to be used by the participating organizations. At the beginning of a megaproject, when novel technologies are initially adopted, project members may not fully understand the technology well neither knowing the appropriate means nor even the consequences of using such technology. Such unfamiliarity leads to high degree of uncertainty about accomplishing project development tasks. Empirical studies have found that megaprojects using novel technology are often less likely to succeed due to their higher level of uncertainty (Tatikonda and Rosenthal 2000). The last source of uncertainty originates from the project's environmental and contextual 
371 factors, and that may preclude the effective use of mechanisms to safeguard and enforce a

372 business relationship (Anderson and Weitz 1989). Environmental uncertainty refers to the rate

373 of change and the degree of unpredictability in the environment and generated by resource

374 scarcity and by a lack of perfect knowledge about environmental fluctuations (Dess and Beard

375 1984). Such environmental uncertainty may lead to information asymmetry among parties and enable participating organizations to behave opportunistically.

The optimal response to uncertainty, based on neoclassical contract theory, is to rely on the safeguard of a contract (Carson et al. 2006). Megaproject participants may seek to tie down terms and definitions as a way to remove uncertainties, particularly ambiguity, from a contract.

A specified contract along these lines is one approach to remedy the problems of volatility and

381 ambiguity. In megaprojects, firms often enter into exceptionally complex contracts to deal with uncertain contracting situations. The more complex and complete a contract the less flexible and adaptable it is. Such inflexible contracts create challenges to contractual governance. Ex post adjustments in megaprojects become problematic when all parties need to renegotiate to 385 accommodate changes, substantially weakening or eliminating the contract safeguard 386 capabilities for megaproject participants in conducting relational behavior. Therefore, this study 387 proposes:

Hypothesis 5a (H5a): The higher the project uncertainty, the weaker the positive 389 relationship between contractual term specificity and megaproject participants' relational 390 behavior.

391 Another main challenge of project uncertainty is the difficulty in obtaining useful information (Molm et al. 2009) as information asymmetries place a premium on opportunism 
393 (Williamson 1985). From a review of opportunism in exchange relationships, Crosno and

394 Dahlstrom (2008) found that external uncertainty would increase opportunism by increasing

395 the likelihood that participants would shirk responsibilities and break the agreements to seek

396 their own interests (Katsikeas et al. 2009). Under such circumstance, the increased opportunism

397 dampens inter-organizational commitment, resulting in less relational behavior. Clauses for contractual contingency adaptability are devised to address different environmental scenarios,

399 especially unpredicted environmental changes. With adaptable approaches and contingency

400 procedures for dealing with such inevitable changes, megaproject participants could deal with

401 uncertainties in a flexible way to decrease conflicts, contributing to the more relational behavior.

402 Therefore, this study proposes:

Hypothesis $5 b(\mathrm{H} 5 \mathrm{~b})$ : The higher the project uncertainty, the stronger the positive relationship between contractual contingency adaptability and megaproject participants' relational behavior.

In contrast, trust may overcome the inflexibility disadvantages of contractually-based

407 governance in a turbulent environment. Trust provides the flexibility to cope with inevitable

408 uncertainties that arise in a long-term exchange. Such flexibility helps mitigate exchange

409 hazards under uncertainties and strengthens bilateral commitment to exchange-specific

410 investments (Luo 2002). Thus, flexibility enables firms to adapt to unforeseeable technological

411 and market changes. High uncertainty, especially in transition economies like China (Zhou et

412 al. 2003), is likely to reinforce the cultivation of trust between contracting partners. From

413 another perspective, trust is supposed to absorb the environmental uncertainty through joint

414 planning and problem solving (Nyaga et al. 2010). Megaproject participants may employ trust 
to manage an environment that is more turbulent than each can cope with alone (Morgan and Hunt 1994). The following hypotheses were therefore proposed:

Hypothesis 6 (H6): The higher the project uncertainty, the stronger the positive relationship between trust and megaproject participants' relational behavior.

\section{Relational Behavior and Team Performance}

Pertinent studies have proposed a positive relationship between inter-firm relational behavior and performance in a supply chain. For example, particularly cooperative behavior, such as flexibility, shared problem-solving, voluntary information exchange, and restraint in the use of power, can improve the performance of a supply chain (Singh and Teng 2016; Koolwijk et al. 2018). Johnston et al. (2004) found that increased cooperative behavior contributes to higher perceived performance and satisfaction among the buyer firms. Research also shows that partners who share critical, accurate, and sensitive information in a timely manner are more successful than those do not exhibit relational behaviors (Chen et al. 2004).

Although relational behavior may increase the integrated value of megaprojects, the sustainability of such behavior depends on how much of the value is captured by each participating organization (Bowman and Ambrosini 2000). Paulraj et al. (2008) pointed out that through effective and efficient information sharing between participating organizations, performance-related errors can be reduced and, task efficiency and stakeholder satisfaction of individual team can be improved. Especially, when sharing important information regarding megaproject design issues and materials procurement, participating organizations are more likely (1) to improve the quality of the megaproject (Carr and Kaynak 2007), (2) to reduce response time, (3) to reduce the costs of protecting against opportunistic behavior, and (4) to 
increase cost savings through operational efficiencies (Carr and Pearson 1999). Moreover, relational behavior also enables participating organizations to make dependable delivery, hence leading to a high level of project integration and positively contributing to obtaining the loyalty of project participants.

A high degree of solidarity of participants' relational behavior, such as joint planning and joint problem solving, is expected to contribute to a high level of perceived satisfaction and team performance. For instance, joint planning could facilitate the efficiency of business transactions between megaproject participants and improve a team's time performance by reducing the risk of unexpected problems and a sophisticated negotiation process. As for joint problem solving, it allows for creative forms of dealing with disagreements and other contingencies of business relationships, contributing to the reduction of transaction costs and improving the cost performance of individual teams. Besides, joint problem solving could promote knowledge transfer between contracting parties by allowing parties to learn from each other through experience, observation, and/or demonstration (Cai et al. 2009), resulting in the higher task efficiency of an individual team. Finally, megaproject participating organizations closely engaging in the current project could build strong social relations for future business collaboration (Lu and Yan 2007). Thus, it is hypothesized that:

Hypothesis 7 (H7). The relational behavior of megaproject participants has a positive effect on their team performance.

After consolidating all hypotheses into a framework, the conceptual model can be established and shown in Fig. 1. 


\section{RESEARCH METHOD}

To test the research model and hypotheses, a questionnaire survey was developed based on literature review, refined through a pilot study, and subsequently used for the data collection and analysis.

\section{Measurements}

The development of measurement began with an investigation of the theoretical and empirical literature on inter-organizational relationship governance. Then the identified measurement items used for the constructs were modified based on the context of megaprojects. Specifically, the measures of contractual governance mechanisms concentrated on the contractual term specificity and contractual contingency adaptability in megaprojects, which were reflective constructs composed of three items and two items, respectively, based on the measures reported in the studies of Jap and Ganesan (2000), Goo et al. (2009) and, Luo (2002). Trust that reflects the confidence of participating organizations in others' reliability and integrity was also a reflective construct measured by five items referring to the study of $\mathrm{Lu}$ et al. (2015). To measure institutional support, two reflective items were used to assess the government's support for and protection of megaprojects (Li and Atuahene-Gima 2001). Consistent with the literature of Hoppner and Griffith (2011), relational behavior was operationalized as a second-order reflective construct composed of three sub-constructs: solidarity, flexibility, and information sharing. Project uncertainty was captured by three items describing change and instability of the external environment, technology, and task during a megaproject's lifecycle (Yan and Dooley 2013). Based on the work of Lu et al. (2015) and interviews with field practitioners, team performance was operationalized as a reflective construct 

performance, (d) building long-term partnerships, and (e) collaborating joint projects in the future. Table 2 presents all constructs, along with their measurement items. studies to have a potential influence on relational behavior, namely prior collaborative experience with other participating organizations ("prior collaborative experience"), project duration, and project delivery method. Relational behavior may be influenced by the historical interactions among participating organizations as prior experience determines their familiarity and trust development (Buvik and Rolfsen 2015; Zhang et al. 2009). In terms of project duration,

491 a longer duration is generally expected to cultivate the development of a high-quality relationship (Levinthal and Fichman 1988), thus, in turn, facilitating relational behavior.

493 Previous research also suggested that project performance varies under different project 494 delivery methods (Ling et al. 2004), such as design-bid-build (DBB), design-build (DB), and 495 EPC, as each delivery method indicates distinct organizational behaviors and team 496 collaboration. Regarding measurement, megaproject duration was scaled with a dummy 497 variable: duration less than 3 years $(=1)$ and above 3 years $(=2)$. Project delivery method was 498 treated as a categorical variable, including DBB, EPC, DB, and other methods. The prior 499 collaborative experience was measured by asking respondents whether they had historical 500 cooperative experience with contracting partners based on a dichotomy variable $(0=$ without 501 prior collaborative experience, $1=$ with prior collaborative experience). 


\section{Sampling and Data Collection}

Based on a comprehensive literature review, we developed a pilot survey questionnaire that was evaluated by 26 experienced practitioners: 6 clients, 9 contractors and 11 consultants. By considering the feedback and comments provided, we evaluated the content validity of the items and tested measurement purification prior to the finalization of the questionnaire and the execution of the survey. After removing one inappropriate item, splitting one item into two, and rephrasing items that were not explicitly described, we present the final version of the measurement items in Appendix S1 in the Supplemental Data.

The governance mechanisms are primarily designed and reinforced by megaproject clients (including governmental officials involved as clients) to manage inter-organizational relationships effectively, especially between them and service providers (refer to as "consultants" and "contractors"). Thus, we selected the consultants and contractors as "key informants" for data collection to investigate the effectiveness of various governance mechanisms on their relational behavior. The use of key informants of one contracting party as data sources to understand the inter-organizational relationship has been widely adopted in past studies (Goo et al. 2009; Paulraj et al. 2008; Shiu et al. 2014). Ning and Ling (2013) emphasized that the consultants' and contractors' behavior is of great importance to high-quality interorganizational relationships though they are reluctant to conduct relational behavior. In the survey, key informants are primarily referred to as project managers who were intimately involved with megaproject governance and have abundant knowledge about interorganizational relationships.

Large companies that often participate in megaprojects were approached to complete the 
questionnaire, including China Railway Group, China State Construction Company, Shanghai Construction Group Company, Tongji Architectural Design Group, CCDI Group, and Shanghai Hua Dong Engineering Corporation. These companies are all listed among the Top 20 in the 2015 ENR Top Chinese Contractors and 2015 ENR Top Chinese Design Firms. Two criteria were adopted to identify qualified participants in the above companies, namely, those who have worked or are working on projects costing over 1 Billion RMB (Chinese Currency) (He et al. 2015) and those holding senior-level positions in their firm such as directors or managers. To maximize the number of qualified respondents, a snowball sampling technique was used; that is, all respondents to the survey were asked to refer other eligible individuals who might be interested in participating.

The survey was completed between January and July 2016. A total of 238 responses were collected from the 737 questionnaires distributed among potential project consultants and contractors $(32.3 \%$ response rate). We then cleaned the raw data by deleting incomplete questionnaires. The final sample consists of 202 responses, in which $42.6 \%, 37.1 \%$, and $20.3 \%$ were collected on the spot, via an online survey, and by email, respectively. The answers from the three types of collection were compared through one-way analysis of variance (ANOVA), revealing no significant differences at the significance level of 0.05 among them. Hence, the data from all three sources were used for the analysis without distinction.

Among all megaprojects indicated by respondents, $84.2 \%$ cost $1-5$ billion RMB and $15.8 \%$ cost over 5 billion RMB. Regarding project duration, $46.5 \%$ were completed in $2-3$ years and $53.5 \%$ were completed longer than three years. Furthermore, $71.8 \%$ of the projects were public and $28.2 \%$ were private projects. A majority of the megaprojects $(86.1 \%)$ adopted design-bid- 
build (DBB) as the delivery method while the remaining $13.9 \%$ employed other methods, such as engineering, procurement, and construction (EPC), and design-build (DB). The rest of the characteristics for these megaprojects and the survey respondents are shown in Table 3.

\section{(Insert Table 3 here)}

To further validate the data quality and address two common issues concerning survey methodology, i.e., non-response bias and common method variance (Podsakoff et al. 2003), a series of additional tests have been performed. Non-response bias was evaluated by testing significant differences between the responses of the first 30 received surveys and that of the last 30 received surveys (Armstrong and Overton 1977). In this survey, both T-test and ANOVA results revealed that no significant differences existed. The possibility of common method variance for all variables was then examined via Harman's one-factor test because respondents were requested to answer questions on both the dependent and independent variables (Podsakoff et al. 2003). The result satisfied the required threshold $(26.53 \%<50 \%)$ regarding the ratio of the first factor accounting for the overall variance.

\section{ANALYSIS AND RESULTS}

To validate the proposed hypotheses, two steps were conducted. First, we estimated the model's reliability and validity by using partial least square structural equation modeling (PLSSEM) and confirmatory factor analysis. Second, we tested the theoretical model with hierarchical moderated regression analyses.

In the first step, the validity of all constructs, including their internal consistency, indicator reliability, convergent validity, and discriminant validity, were assessed (Hair et al. 2011; Le et al. 2014), with the results presented in Tables 4 and 5. Table 4 displays the descriptive statistics 
and correlations for each construct and Table 5 shows that the composite reliability (CR) of each construct was validated $(C R>0.70)$ and the results satisfied the requirement of internal consistency (Hair et al. 2014). The indicator reliability was also assessed by examining the loadings of the multiple items on their corresponding constructs, showing that all factor loadings were statistically significant $(p<0.001)$. The result that average variance extracted (AVE) of all constructs were greater than 0.50 showed that each item is strongly related to its latent construct, in support of convergent validity. The discriminant validity used to reflect the difference between two latent constructs is confirmed in both Table S1 of Appendix S2 and Table S2 in the Supplemental Data.

Regarding the second-order construct — relational behavior, we evaluated the reliability and validity as well. Firstly, all the outer loadings of eight measurements are well above the critical value of 0.70 . Specifically, the relational behavior's composite reliability $(0.84)$ is greater than the critical value of 0.70 , thus supporting internal consistency reliability. The AVE of relational behavior has a value of 0.51 , also providing evidence of convergent validity. Furthermore, based on the result of correlations of variables in Table 4, the square root of the AVE for relational behavior in the diagonal was greater than its highest off-diagonal value (Hair et al. 2014), providing evidence of discriminant validity among the theoretical constructs. Finally, it is verified that the relational behavior has strong relationships with its first-order constructs — solidarity (0.73), flexibility (0.66) and information sharing (0.82). Hence, all firstorder constructs are sufficiently highly correlated for their second-order construct (i.e., relational behavior) with high level of explanation for more than $50 \%$ of each first-order construct's variance. 


\section{(Insert Table 4 here)}

(Insert Table 5 here)

In the second step, because the proposed model contains interaction terms between governance mechanisms and project uncertainty, hierarchical moderated regression analysis was used for validation (Liu et al. 2009) and the results are presented in Table 6. The baseline model (Model 1 in Table 6) contains control variables as the only inputs. The results revealed that control variables were not significantly related to relational behavior, as they accounted for only $1 \%$ of the variance in relational behavior. Model 2 adds three kinds of governance mechanisms - contractual term specificity (X1), contractual contingency adaptability (X2), trust (X3), institutional support (X4) and the moderator — project uncertainty (X5), resulting in increasing the predictive power $\left(\Delta R^{2}=0.32, F=11.95, p<0.001\right)$ in explaining the variance of relational behavior. Model 3 features all the interactive effects between governance mechanisms and project uncertainty on relational behavior. Prior to the creation of the interaction terms in Model 3, the independent variables were centered to reduce multicollinearity (Aiken and West, 1991) and the variance inflation factors (VIF) was calculated for every regression equation. The result indicates that the maximum VIF of the model (3.50) meets the requirement of VIF $<10$ (Nachtsheim and Chris 2004). The addition of the interaction terms in Model 3 further increased the R-square value than Model $2\left(\Delta R^{2}=0.05, F=8.99, p\right.$ $<0.01$ ), in support of the significant moderating effects of project uncertainty. Finally, we assessed the effect of relational behavior on team performance in Model 4, in which the explained variance was significant $\left(R^{2}=0.32, F=93.54, p<0.001\right)$. 
611

612

613

614

615

616

617

619

620

621

622

623

624

625

626

627

628

629

630

631

632

\section{Main Effect}

The results in Model 3, demonstrate that term specificity had a significant, positive effect on relational behavior $(\beta=0.23, p<0.01)$, providing support for H1a, whereas contractual contingency adaptability was found to have no significant effect on influencing relational behavior $(\beta=-0.01, n . s$.$) , not in support of H1b. These results corroborate previous$ recommendations to distinguish contractual term specificity and contingency adaptability and to examine their differential impacts (Luo 2002). The results also suggest that trust $(\beta=0.29$, $p<0.001$ ) was positively related to relational behavior, in support of $\mathrm{H} 2$, and institutional support significantly increased relational behavior in megaprojects $(\beta=0.19, p<0.001)$, in support of $\mathrm{H} 3$, revealing the necessity to take institutional support into account. $\mathrm{H} 7$, which predicted that relational behavior was positively related to team performance of participating organizations, was also supported $(\beta=0.57, p<0.001)$. However, the main effect of project uncertainty slightly facilitates relational behavior of megaproject participants, though not significantly $(\beta=0.04$, n.s. $)$.

\section{Moderating Effect}

By examining the path coefficients of the interaction variable on relational behavior, we suggest that contractual term specificity and trust increase relational behavior complementarily in megaprojects $(\beta=0.57, p<0.001)$, supporting H4a. In contrast, contractual contingency adaptability and trust are neither pure substitutes nor complements (Model 3: $\beta=-0.09$, n.s.).

Thus, our results do not support H4b.

$\mathrm{H} 5 \mathrm{a}$ and $\mathrm{H} 5 \mathrm{~b}$ predicted the moderating influence of project uncertainty on the relationship between contractual governance and relational behavior. Seen from Model 3, the coefficient of 
633

634

635

636

637

638

640

641

642

643

644

645

646

647

648

649

650

651

652

653

654 contractual governance multiplied by project uncertainty is negative and significant $(\beta=-0.35$,

$p<0.001)$. Thus, project uncertainty negatively moderates the relationship, and H5a is supported. Meanwhile, the coefficient of contractual contingency adaptability is positive and significant in Model $3(\beta=0.18, p<0.1)$, thus H5b is also supported. Regarding the interplay of trust and project uncertainty, in line with our prediction, the results indicate that project uncertainty positively moderates the relationship between trust and relational behavior $(\beta=$ $0.13, p<0.1)$, in support of $\mathrm{H} 6$.

To further interpret these moderating effects, the respective effects of contract and trust on relational behavior for low and high levels of project uncertainty are plotted in Fig. 2. The calculation of the simple slopes and their significance levels was based on Aiken et al. (1991) approach. Fig. 2(a) reveals that the sloped regression line for the relationship between contractual term specificity and participating organizations' relational behavior was negative and not significant for high project uncertainty $(\beta=-0.08, n$.s. $)$, but was positive and significant for low project uncertainty $(\beta=0.54, p<0.001)$, in support of H5a of the negative moderating effect. In contrast, the positive moderating effect of project uncertainty was confirmed in both Figs. 2(b) and 2(c). In Fig. 2(b), project uncertainty strengthened the effect of contractual contingency adaptability on participating organizations' relational behavior, though the relationships between them were both nonsignificant $(\beta=-0.16)$ for low project uncertainty and $\beta=0.14$ for high project uncertainty. Similarly, in Fig. 2 (c), trust had a minor positive effect on participating organizations' relational behavior when comparing high project uncertainty $(\beta=0.42, p<0.001)$ to low uncertainty $(\beta=0.16$, n.s. $)$, in line with H6.

(Insert Table 6 here) 


\section{DISCUSSION AND VALIDATION}

657

658

659

660

661

663

664

665

666

667

668

669

670

671

672

673

674

675

676

By examining the impact of three distinctive governance mechanisms that link participating organizations' relational behavior to their performance outcomes, this study provides significant evidences to support the hypotheses $\mathrm{H} 1 \mathrm{a}, \mathrm{H} 2$ and $\mathrm{H} 3$ by confirming the determinants of contractual term specificity, trust and institutional support in promoting relational behavior, which in turn facilitates team performance of megaproject participants $(\mathrm{H} 7)$. In addition, it is worth noting that the findings of this study favored a differentiated result for contractual term specificity (H5a) and contractual contingency adaptability (H5b) when the respective effects on participants' relational behavior are moderated by different levels of project uncertainty, supporting H5a but not supporting H5b.

\section{The Effect of Governance Mechanisms on Relational Behavior}

Among various forms of governance mechanisms, including contractual term specificity, trust, and institutional support, trust acts as the most effective driver to positively impact project participants' relational behavior, particularly the contract mechanism. This result is similar to pertinent studies in other fields. For example, Wu et al. (2017b) demonstrated that trust is more important than contracts for the performance of cooperative innovation projects in high-tech enterprises. Trust grants information sharing to access the valuable knowledge of project participants, and facilitates the acquisition of novel ideas and insights that lay the groundwork for problem-solving. This is true for both innovation-driven enterprises and megaprojects that demand massive, accurate, and quickly-responding information from various suppliers, and in which the cooperation process among participants is complex. Therefore, as a self-enforcing 
677 safeguard, the presence of trust is based on mutual commitment and shared values among contracting partners and it is a more effective and less costly alternative to creating a contract (Dyer and Singh 1998).

Another plausible explanation for the greater role of trust is that many studies endorse the importance of guanxi (literally, interpersonal relationships or connections) in the context of China. Interpersonal guanxi helps determine whether firms gain influence in exchanging relationships (Zhuang et al. 2008). In Chinese culture, trust is based on a high level of guanxi, which is the lifeblood of business-making. Guanxi is utilitarian in developing a friendship that consists of personal ties or social bonds to share resources in business communities and is described as the informal connection essential to gain approval for or access to key resources in China (Wu et al. 2017a). Therefore, we argue that the nature of megaprojects and Chinese culture make trust more important than contracts to build relational behavior.

In addition, the results indicate that institutional support can predict relational behavior (H4). This, in part, supports the work of Zhai (2017) in which institutional support could significantly influence the coordination in megaprojects. Megaprojects need specific governance regimes that can adapt to their societal contexts for efficient supervision and coordination. The administration not only imposes influences through legislation, but also proactively exercises its power on various organizations through its regulatory or administrative control so as to support the smooth implementation of megaprojects. Thus, megaproject participants are more willing to conduct information sharing, behavioral flexibility and solidarity with the intention to develop a political network with the government. A supportive political network might bring participating organizations favorable policy and scarce resources, 
699

such as subsidies and tax breaks, and win future business opportunities in tendering other governmental-invested projects.

\section{The Effect of Contractual Term Specificity and Contingency Adaptability on Relational}

\section{Behavior}

The role of the contract is divided into two aspects in megaprojects. In one way, the result shows that more specific contractual terms promote better relational behavior of megaproject participants. This finding is consistent with Goo et al. (2009) who provided evidence in favor of using a well-structured agreement in an IT outsourcing engagement. Due to the selfenforcing nature of relational behavior, participating organizations have to rely much more on contractual term specificity to constrain their partners because they are not familiar with each other in the early stage (Luo 2002). A well-structured agreement would supply megaproject engagements with a "safety net" in lieu of exclusive reliance on trust. Thus, specified contracts are regarded as the basis to initiate megaprojects.

From another respective, however, our result did not support the significant effect of contractual contingency adaptability on relational behavior. This seems to contradict to the finding of Lui (2009) where the relationship between contingency adaptability and relational performance is significant. One plausible explanation is that unlike normal-sized projects that can be easily planned, it is hard to predict all the contingencies in a megaproject due to highly interdependent works and lack of experience on similar megaprojects (Tanriverdi et al. 2007). In addition, when contingencies occur and lead to changes in the formal contract, it is preferred to be negotiated in a continuously interactive environment, whereas mutual adjustment and reciprocal on contract changes can be more effective, rather than in an environment where 
contract changes settled by a standardized approach or by any specified plans, procedures, and schedules prescribed in a megaproject contract.

In addition, the findings provide an in-depth understanding about the relationship between the two types of contractual mechanisms and trust by showing that contractual term specification has a significant complementary relationship with trust to enhance the relational behavior of megaproject participants. This is because explicit clauses that help develop social elements in relational exchanges include a higher level of trust that is usually associated with hierarchies (Stinchcombe and Heimer 1985). Yang et al. (2011) also emphasized that a specified contract combined with trust significantly reinforces the long-term orientation. Thus, this research provides strong evidence that specified formal contracts can be utilized to develop both trust and relational behavior. However, contractual contingency adaptability was found to be neither substitutes nor complements with trust.

Another difference between these two roles of the contract is that the effect of contractual term specificity on relational behavior is weakened by uncertainty. This is consistent with previous studies that argued that formal controls may not be suitable in high uncertainty and equivocality projects because they impose constraints on the professionals involved and limit their freedom and innovation capacity (Hope and Fraser 2003). Moreover, a high level of technology and environmental uncertainty makes it difficult to pin down the terms and clauses, thus weakening the safeguard effect of contractual term specificity.

\section{MANAGERIAL IMPLICATIONS}

The findings of the current study clarify the research and offer three effective implications for both project participants and policy makers seeking to promote the adoption of relational 
behavior in megaprojects through appropriate governance mechanisms.

First, participating organizations need to develop a well-structured contract between contracting parties at the outset with a high proportion of clauses representing contractual term specificity and with a medium proportion reflecting contractual contingency adaptability. A lack of term specificity leads to erroneous conclusions pertaining to the contract's value in interacting with trust and promoting relational behavior. Therefore, each party's rights and obligations should be detailed in writing and unambiguously specified to safeguard exchange hazards with the intention to promote relational behavior. In terms of contractual contingency adaptability, the parties concerned should not have excessive processes and methods for various contingencies and contract changes prescribed in the megaproject contract. Such complex clauses highlighting contingency adaptability will increase transaction cost but add no significant value to relationship management. When confronting different scales of megaprojects, project managers should adjust both contractual term specificity and contractual contingency adaptability according to the level of project uncertainty. For a high degree of megaproject uncertainty, managers can relatively increase the degree of contingency adaptability, such as to set an emergency response clause for quick and efficient onsite decision, as well as decrease the focus on term specificity for promoting the implementation of relational behavior. Comparatively, more term specificity and less contingency adaptability should be set for a megaproject with certain scope and standard, so parties can exhibit their behavior in a more regulated manner.

Second, megaproject participants must attach both the importance of trust and contractual term specificity because they are mutually complementary to enhance relational behavior. 
765 Cultivating mutual trust of megaproject participants cannot be ignored while spending efforts

766 in drafting contracts with their business partners. Trust-building tools, such as relationship

767 workshops, are encouraged to be used in megaprojects so as to facilitate open communication,

768 build relationships, achieve mutual understanding, and to generate innovative programs that

769 promote coordination (Chen and Manley 2014). For instance, a trust-bond activity can be arranged to precede or accompany the contract negotiation process so as to obtain the mutual trust. Then both parties are more engaged and efficient to straightforwardly focus on reviewing contractual terms rather than wasting time on suspicious doubts, so negotiation time and efforts can be saved. Through the reciprocal process of fulfilling one contractual term and entering another, the mutual trust is further enhanced to cultivate the friendly environment not only benefiting the contract negotiation but also creating the harmonized relationship between both parties.

Third, government officials should endeavor to support the implementation of megaprojects in transition economies like China, where successful megaproject management often leverages the government's power to exert its influence on coordination and control. For example, megaprojects adopt a special leadership committee to integrate all project participants to provide vision, governance, and leadership (Chen and Manley 2014), and the officials of

782 Chinese central and local governments are typically delegated as major leaders in providing 783 strong support for the megaprojects, and, thereby, promote project participants' solidarity, 784 flexibility, and information sharing. Further, enhancing relational behavior within a 785 megaproject, project participants are expected to build social capital with the government to win benefits in the long-run. 


\section{CONCLUSIONS}

High levels of relational behavior between project participating organizations are vital for the success of relationship management in megaprojects. Focusing on the governance perspective, this study developed a theoretical model showing the relationships between contract, trust, and institutional support, and the association between relational behavior and team performance. Then, a sample of 202 managers of consultants and contractors in Chinese megaprojects were collected and analyzed by hierarchical moderated regression analyses.

Three main findings were discussed. First, three subcategories of governance mechanisms — contractual term specificity, trust, and institutional support—are all significant in improving relational behavior and among them, trust is most effective, indicating that informal mechanisms like trust are relatively better facilitators of relational behavior than formal mechanisms, such as contract. Second, regarding the interaction of contract and trust on relational behavior, it is confirmed that contractual term specificity and trust are complements rather than substitutes, while contractual term specificity and trust are neither pure complements nor substitutes. Third, the moderating effect of project uncertainty was particularly important, exhibiting mixed effects - positively moderating both the relationships between trust and relational behavior, and between contractual contingency adaptability and relational behavior-yet negatively moderating the relationship between contractual term specificity and relational behavior. The findings of the present study offer three key insights for stakeholders seeking to use appropriate governance mechanisms to promote the adoption of relational behavior in megaprojects, namely developing a well-structured contract for megaproject implementation, attaching importance of both trust and contractual term 
809

810

811

specificity, and calling for more institutional support for megaproject relationship management.

This paper contributes to the theory of megaprojects inter-organizational relationship in three aspects. First, the study contextualizes multiple theories in megaprojects to examine the characterization of relational behavior and identifies three key paths influencing relational behavior via reinforcing contractual governance, increasing mutual trust, and offering institutional support. These paths switch on or off depending on the megaproject uncertainty. As the three paths reveal different aspects of project governance, understanding their roles is significant to improve relationship management in megaprojects.

Second, the current study provides new insights into contractual governance theory by expanding the boundary of studying contractual governance as a unidimensional construct. This study examines two differential roles-both term specificity and contingency adaptability, in facilitating relational behavior among megaproject participants. The results imply that contractual term specificity intensifies inter-organizational relational behavior, whereas the effect of contractual contingency adaptability is not significant. Besides, it is also confirmed that term specificity and trust are mutually complemented in megaprojects, contributing to the long-standing debate on the topic of "substitutes versus complements" for the relationship between contractual governance and relational governance.

Last, this study demonstrates the facilitating role of the government through its institutional support for relational behavior in megaprojects. Previous studies normally assume full enforcement of contractual mechanism and relational mechanisms on inter-organizational relationships but ignore the role of the government under different institutional environments, especially in transition economies. Researchers have called for more assessments of the 
831 institutional support provided to megaproject development (Grewal and Dharwadkar 2002),

832 though empirical evidence is still scarce. This study presents an initial attempt to assess and

833 confirm that the institutional support has profound effects on strengthening the inter-

834 organizational relationship among megaproject participants.

835 Despite these theoretical contributions mentioned above, the interpretation of the

836 findings should be made carefully due to three limitations that must be addressed in future

837 endeavors. The first limitation is the use of a one-time survey of megaproject participants while

838 ignoring the dynamic process of relational behavior that changes over time, during which

839 participating organizations may adjust their governance strategies and collaborative decisions.

840 Besides, a self-reporting survey was employed to collect behavior information from one

841 contracting party, which is inevitably subject to the bias perceived by one side. Future research

842 could take a longitudinal perspective to examine how governance mechanisms and relational

843 behavior evolve and change over time, and consider to gather matched-dyad data from paired

844 informants, such as collecting information from both clients and contractors in the same

845 megaproject.

846 The second limitation is that the study mainly considers the interaction between

847 contractual mechanisms and trust, without considering other moderating effects (i.e., project

848 uncertainty and institutional support). Further studies are recommended to extend the

849 inclusiveness of the governance model that incorporate more interaction effects and potential

850 moderators in megaprojects. The third limitation is that the empirical data in this study were all

851 collected from megaprojects in China, so the application of the findings to other countries

852 should be performed with caution and appropriate adjustments. For instance, China's culture of 
853

guanxi fosters the popularization of network-centered rather than market-centered strategies in business operations (Peng 2003). In contrast, in most developed countries, the contract is a more effective governance mechanism for promoting inter-organizational exchange. A wider scope of data collection across different countries and regions could provide valuable information that would expand the generalization of the research results.

\section{ACKNOWLEDGMENT}

This work is partially supported by the China Scholarship Council (Grant number: 201506260076) for offering one-year jointed Ph.D. program at the National University of Singapore. The authors gratefully acknowledge the Fundamental Research Funds for the Central Universities for providing support to this research effort.

\section{SUPPLEMENTAL DATA}

Appendixes S1 and S2, and Tables S1 and S2, are available online in the ASCE Library (www.ascelibrary.org).

\section{REFERENCE}

Ahola, T., Ruuska, I., Artto, K., and Kujala, J. (2014). "What is project governance and what are its origins?" International Journal of Project Management, 32(8), 1321-1332.

Aiken, L. S., West, S. G., and Reno, R. R. (1991). Multiple regression: Testing and interpreting interactions, Sage, Thousand Oaks, California.

Anderson, E., and Weitz, B. (1989). "Determinants of Continuity in Conventional Industrial Channel Dyads." Marketing Science, 8(4), 310-323.

Armstrong, J. S., and Overton, T. S. (1977). "Estimating nonresponse bias in mail surveys." Journal of marketing research, 396-402.

Arranz, N., and Arroyabe, J. C. F. D. (2012). "Effect of Formal Contracts, Relational Norms and Trust on Performance of Joint Research and Development Projects." British Journal of Management, 23(4), 575-588.

Beatty, J. F., and Samuelson, S. S. (1990). "Business Law and the Legal Environment, Standard Edition, 6th Edition." 9(2), 175-184.

Bowman, C., and Ambrosini, V. (2000). "Value Creation Versus Value Capture: Towards a Coherent Definition of Value in Strategy." British Journal of Management, 11(1), 1-15.

Burkert, M., Ivens, B. S., and Shan, J. (2012). "Governance mechanisms in domestic and international buyer-supplier relationships: An empirical study." Industrial Marketing Management, 41(3), 
544-556.

Buvik, M. P., and Rolfsen, M. (2015). "Prior ties and trust development in project teams"CA case study from the construction industry." International Journal of Project Management, 33(7), 14841494.

Cai, S., Yang, Z., and Hu, Z. (2009). "Exploring the governance mechanisms of quasi-integration in buyer-supplier relationships." Journal of Business Research, 62(6), 660-666.

Caniëls, M. C. J., and Gelderman, C. J. (2010). "The Safeguarding Effect of Governance Mechanisms in Inter - firm Exchange: The Decisive Role of Mutual Opportunism." British Journal of Management, 21(1), 239-254.

Cannon, J. P., Achrol, R. S., and Gundlach, G. T. (2000). "Contracts, norms, and plural form governance." Journal of the Academy of Marketing Science, 28(2), 180-194.

Cao, Z., and Lumineau, F. (2015). "Revisiting the interplay between contractual and relational governance: A qualitative and meta-analytic investigation." Journal of Operations Management, $33,15-42$.

Carr, A. S., and Kaynak, H. (2007). "Communication methods, information sharing, supplier development and performance: An empirical study of their relationships." International Journal of Operations \& Production Management, 27(4), 346-370.

Carr, A. S., and Pearson, J. N. (1999). "Strategically managed buyer-supplier relationships and performance outcomes." Journal of Operations Management, 17(5), 497-519.

Carson, S. J., Madhok, A., and Wu, T. (2006). "Uncertainty, opportunism, and governance: The effects of volatility and ambiguity on formal and relational contracting." Academy of Management Journal, 49(5), 1058-1077.

Che, K. I. C. I., Costello, S. B., and Wilkinson, S. (2015). "Establishment of Quantitative Measures for Team Integration Assessment in Alliance Projects." Journal of Management in Engineering, 31(5), 04014075.

Chen, C., Zhu, X., Ao, J., and Cai, L. (2013). "Governance Mechanisms and New Venture Performance in China." Systems Research \& Behavioral Science, 30(3), 383-397.

Chen, I. J., Paulraj, A., and Lado, A. A. (2004). "Strategic purchasing, supply management, and firm performance." Journal of Operations Management, 22(5), 505-523.

Chen, L., and Manley, K. (2014). "Validation of an instrument to measure governance and performance on collaborative infrastructure projects." Journal of Construction Engineering and Management, 140(5), 04014006.

Chen, P., and Partington, D. (2004). "An interpretive comparison of Chinese and Western conceptions of relationships in construction project management work." International Journal of Project Management, 22(5), 397-406.

Chi, C. S. F., and Javernick - Will, A. N. (2011). "Institutional effects on project arrangement: high speed rail projects in China and Taiwan." Construction Management \& Economics, 29(6), 595611.

Chi, C. S., Ruuska, I., Levitt, R., Ahola, T., and Artto, K. (2011). "A Relational Governance Approach for Megaprojects: Case Studies of Beijing T3 and Bird's Nest Projects in China." Proceeding of EPOC 2011 Conference.

Claro, D. P., Hagelaar, G., and Omta, O. (2003). "The determinants of relational governance and performance: how to manage business relationships?" Industrial Marketing Management, 32(8), 703-716. 
Crosno, J. L., and Dahlstrom, R. (2008). "A meta-analytic review of opportunism in exchange relationships." Journal of the Academy of Marketing Science, 36(2), 191-201.

Das, T. K., and Teng, B. S. (2001). "Relational Risk and Its Personal Correlates in Strategic Alliances." J. Bus. Psychol., 15(3), 449-465.

Davies, H., and Walters, P. (2004). "Emergent patterns of strategy, environment and performance in a transition economy." Strategic Management Journal, 25(4), 347-364.

Dess, G. G., and Beard, D. W. (1984). "Dimensions of Organizational Task Environments." Administrative Science Quarterly, 29(1), 52-73.

Dooley, K. J., and Ven, A. H. V. D. (1999). "Explaining Complex Organizational Dynamics." Organization Science, 10(3), 358-372.

Doz, Y. L. (1996). "The Evolution of Cooperation in Strategic Alliances: Initial Conditions or Learning Processes?" Strategic Management Journal, 17(S1), 55-83.

Dwyer, F. R., Schurr, P. H., and Oh, S. (1987). "Developing Buyer-Seller Relationships." Journal of Marketing, 51(2), 11-27.

Dyer, J. H., and Singh, H. (1998). "The relational view: Cooperative strategy and sources of interorganizational competitive advantage." Academy of management review, 23(4), 660-679.

Eisenhardt, K. M. (1985). "Control: Organizational and Economic Approaches." Management Science, 31(2), 134-149.

Flyvbjerg, B. (2011). "Over budget, over time, over and over again: managing major projects. The Oxford Handbook of Project Management." Oxford University Press.

Flyvbjerg, B. (2014). "What you should know about megaprojects and why: an overview." Project Management Journal, 45(2), 6-19.

Fryxell, G. E., Dooley, R. S., and Vryza, M. (2002). "After the ink dries: The interaction of trust and control in US - based international joint ventures." Journal of Management Studies, 39(6), 865886.

Goo, J., Kishore, R., Rao, H. R., and Nam, K. (2009). "The role of service level agreements in relational management of information technology outsourcing: an empirical study." MIS Quarterly, 119145.

Grewal, R., and Dharwadkar, R. (2002). "The role of the institutional environment in marketing channels." Journal of Marketing, 66(3), 82-97.

Griffith, D. A., and Myers, M. B. (2005). "The performance implications of strategic fit of relational norm governance strategies in global supply chain relationships." Journal of International Business Studies, 36(3), 254-269.

Griffith, D. A., Harvey, M. G., and Lusch, R. F. (2006). "Social exchange in supply chain relationships: The resulting benefits of procedural and distributive justice." Journal of operations management, 24(2), 85-98.

Hair, J. F., Hult, G. T. M., Ringle, C. M., and Sarstedt, M. (2014). A primer on partial least squares structural equation modeling (PLS-SEM), Sage Publications, Thousand Oaks, California.

Hair, J. F., Ringle, C. M., and Sarstedt, M. (2011). "PLS-SEM: Indeed a silver bullet." Journal of Marketing theory and Practice, 19(2), 139-152.

Hanisch, B., and Wald, A. (2011). "A project management research framework integrating multiple theoretical perspectives and influencing factors." Project Management Journal, 42(3), 4-22.

Heide, J. B. (1994). "Interorganizational governance in marketing channels." The Journal of Marketing, $71-85$. 
Heide, J. B., and John, G. (1992). "Do norms matter in marketing relationships?" The Journal of Marketing, 56(2), 32-44.

Hellman, J., and Schankerman, M. (2000). "Intervention, Corruption and Capture: The Nexus between Enterprises and the State." Economics of Transition, 8(3), 545-576.

Henisz, W. J., Levitt, R. E., and Scott, W. R. (2012). "Toward a unified theory of project governance: economic, sociological and psychological supports for relational contracting." Engineering Project Organization Journal, 2(1-2), 37-55.

Hewett, K., and Bearden, W. O. (2001). "Dependence, trust, and relational behavior on the part of foreign subsidiary marketing operations: Implications for managing global marketing operations." Journal of marketing, 65(4), 51-66.

Hinds, P. J., and Mortensen, M. (2005). "Understanding Conflict in Geographically Distributed Teams: The Moderating Effects of Shared Identity, Shared Context, and Spontaneous Communication." Organization Science, 16(3), 290-307.

Hope, J., and Fraser, R. (2003). Beyond Budgeting: How Managers Can Break Free from the Annual Performance Trap, Harvard Business Press.

Hoppner, J. J., and Griffith, D. A. (2011). "The role of reciprocity in clarifying the performance payoff of relational behavior." Journal of Marketing Research, 48(5), 920-928.

Jap, S. D., and Anderson, E. (2003). "Safeguarding interorganizational performance and continuity under ex post opportunism." Management Science, 49(12), 1684-1701.

Jap, S. D., and Ganesan, S. (2000). "Control mechanisms and the relationship life cycle: Implications for safeguarding specific investments and developing commitment." Journal of marketing research, 37(2), 227-245.

Jayaraman, V., Narayanan, S., Luo, Y., and Swaminathan, J. M. (2013). "Offshoring Business Process Services and Governance Control Mechanisms: An Examination of Service Providers from India." Production \& Operations Management, 22(2), 314-334.

Jiang, W., and Lu, Y. (2017). "Influence of initial trust on control from client perspective: Construction industry in China." Engineering Construction \& Architectural Management, 24(2), 326-345.

Jiang, W., Lu, Y., and Le, Y. (2016). "Trust and Project Success: A Twofold Perspective between Owners and Contractors." Journal of Management in Engineering, 32(6), 04016022.

Jiang, X., Li, M., Gao, S., Bao, Y., and Jiang, F. (2013). "Managing knowledge leakage in strategic alliances: The effects of trust and formal contracts." Industrial Marketing Management, 42(6), 983-991.

Johnston, D. A., McCutcheon, D. M., Stuart, F. I., and Kerwood, H. (2004). "Effects of supplier trust on performance of cooperative supplier relationships." Journal of operations Management, 22(1), 23-38.

Katsikeas, C. S., Skarmeas, D., and Bello, D. C. (2009). "Developing Successful Trust-Based International Exchange Relationships." Journal of International Business Studies, 40(1), 132155.

Ke, Y., Ling, F. Y., and Zou, P. X. (2013). Effects of contract strategy on interpersonal relations and project outcomes of public-sector construction contracts in Australia. Journal of Management in Engineering, 31(4), 04014062.

Khalfan, M. M. A., Mcdermott, P., and Swan, W. (2007). "Building trust in construction projects." Supply Chain Management, 12(6), 385-391.

Koolwijk, J. S. J., van Oel, C. J., Wamelink, J. W. F., and Vrijhoef, R. (2018). "Collaboration and 
Integration in Project-Based Supply Chains in the Construction Industry." Journal of Management in Engineering, 34(3), 04018001.

Koufteros, X. A., Vonderembse, M. A., and Doll, W. J. (2002). "Integrated product development practices and competitive capabilities: the effects of uncertainty, equivocality, and platform strategy." Journal of Operations Management, 20(4), 331-355.

Lau, E., and Rowlinson, S. (2009). "Interpersonal trust and inter - firm trust in construction projects." Construction Management and Economics, 27(6), 539-554.

Le, Y., Shan, M., Chan, A. P., and Hu, Y. (2014). "Investigating the causal relationships between causes of and vulnerabilities to corruption in the Chinese public construction sector." Journal of construction engineering and management, 140(9), 05014007.

Levinthal, D. A., and Fichman, M. (1988). "Dynamics of Interorganizational Attachments: AuditorClient Relationships." Administrative Science Quarterly, 33(3), 345-369.

Li, H., and Atuahene-Gima, K. (2001). "Product innovation strategy and the performance of new technology ventures in China." Academy of Management Journal, 44(6), 1123-1134.

Li, J. J., Poppo, L., and Zhou, K. Z. (2010). "Relational mechanisms, formal contracts, and local knowledge acquisition by international subsidiaries." Strategic Management Journal, 31(4), 349-370.

Li, Y., Lu, Y., Ma, L., and Kwak, Y. H. (2018). "Evolutionary Governance for Mega-Event Projects (MEPs): A Case Study of the World Expo 2010 in China." Project Management Journal, 49(1), 57-78.

Ling, F. Y. Y., Chan, S. L., Chong, E., and Ee, L. P. (2004). "Predicting Performance of Design-Build and Design-Bid-Build Projects." Journal of Construction Engineering \& Management, 130(1), 7583.

Liu, Y., Luo, Y., and Liu, T. (2009). "Governing buyer-supplier relationships through transactional and relational mechanisms: Evidence from China." Journal of Operations Management, 27(4), 294309.

Lu, P., Guo, S., Qian, L., He, P., and Xu, X. (2015). "The effectiveness of contractual and relational governances in construction projects in China." International Journal of Project Management, 33(1), 212-222.

Lu, P., Qian, L., Chu, Z., and Xu, X. (2016). "Role of Opportunism and Trust in Construction Projects: Empirical Evidence from China." Journal of Management in Engineering, 32(2), 05015007.

Lu, S., and Yan, H. (2007). "A model for evaluating the applicability of partnering in construction." International Journal of Project Management, 25(2), 164-170.

Lui, S. S. (2009). "The roles of competence trust, formal contract, and time horizon in interorganizational learning." Organization Studies, 30(4), 333-353.

Lui, S. S., Wong, Y. Y., and Liu, W. (2009). "Asset specificity roles in interfirm cooperation: Reducing opportunistic behavior or increasing cooperative behavior?" Journal of Business research, 62(11), 1214-1219.

Lumineau, F., Fréchet, M., and Puthod, D. (2011). "An organizational learning perspective on the contracting process." Strategic Organization, 9(1), 8-32.

Luo, Y. (2002). "Contract, cooperation, and performance in international joint ventures." Strategic management journal, 23(10), 903-919.

Lusch, R. F., and Brown, J. R. (1996). "Interdependency, contracting, and relational behavior in marketing channels." The Journal of Marketing, 60(4), 19-38. 
Macneil, I. R. (1980). "Power, contract, and the economic model." Journal of Economic Issues, 14(4), 909-923.

Malhotra, D., and Lumineau, F. (2011). "Trust and collaboration in the aftermath of conflict: The effects of contract structure." Academy of Management Journal, 54(5), 981-998.

Malhotra, D., and Murnighan, J. K. (2002). "The Effects of Contracts on Interpersonal Trust." Administrative Science Quarterly, 47(3), 534-559.

Memon, S. A., Hadikusumo, B., and Sunindijo, R. Y. (2014). "Using Social Interaction Theory to Promote Successful Relational Contracting between Clients and Contractors in Construction." Journal of Management in Engineering, 31(6), 04014095.

Meng, X. (2012). "The effect of relationship management on project performance in construction." International journal of project management, 30(2), 188-198.

Möller, K., and Svahn, S. (2004). "Crossing East-West boundaries: Knowledge sharing in intercultural business networks." Industrial Marketing Management, 33(3), 219-228.

Molm, L. D., Schaefer, D. R., and Collett, J. L. (2009). "Fragile and Resilient Trust: Risk and Uncertainty in Negotiated and Reciprocal Exchange." Sociological Theory, 27(1), 1-32.

Morgan, R. M., and Hunt, S. D. (1994). "The Commitment-Trust Theory of Relationship Marketing." Journal of Marketing, 58(3), 20-38.

Morris, P. W., and Hough, G. H. (1987). The anatomy of major projects: A study of the reality of project management, Wiley, Chichester.

Myers, P. S. (2007). Strategic and operational autonomy in the governance of multiparty ventures, Harvard University, Cambridge, MA.

Nachtsheim, and Chris (2004). Applied linear regression models, McGraw-Hill/Irwin.

Ni, G., Cui, Q., Sang, L., Wang, W., and Xia, D. (2017). "Knowledge-Sharing Culture, Project-Team Interaction, and Knowledge-Sharing Performance among Project Members." Journal of Management in Engineering, 34(2), 04017065.

Ning, Y., and Ling, F. Y. Y. (2013). "Comparative study of drivers of and barriers to relational transactions faced by public clients, private contractors and consultants in public projects." Habitat International, 40, 91-99.

Ning, Y., and Ling, F. Y. Y. (2014). "Boosting public construction project outcomes through relational transactions." Journal of Construction Engineering and Management, 140(1), 04013037.

Nyaga, G. N., Whipple, J. M., and Lynch, D. F. (2010). "Examining supply chain relationships: do buyer and supplier perspectives on collaborative relationships differ?" Journal of Operations Management, 28(2), 101-114.

Olsen, B. E., Haugland, S. A., Karlsen, E., and Husøy, G. J. (2005). "Governance of complex procurements in the oil and gas industry." Journal of Purchasing \& Supply Management, 11(1), 1-13.

Osipova, E. (2015). "Establishing Cooperative Relationships and Joint Risk Management in Construction Projects: Agency Theory Perspective." Journal of Management in Engineering, 31(6). 05014026

Park, H., Kim, K., Kim, Y. W., and Kim, H. (2017). "Stakeholder management in long-term complex megaconstruction projects: The Saemangeum Project." Journal of Management in Engineering, 33(4), 05017002.

Paulraj, A., Lado, A. A., and Chen, I. J. (2008). "Inter-organizational communication as a relational competency: Antecedents and performance outcomes in collaborative buyer-supplier 
relationships." Journal of operations management, 26(1), 45-64.

Peng, M. W. (2003). "Institutional transitions and strategic choices." Academy of management review, 28(2), 275-296.

Phelps, A. F., and Reddy, M. "The influence of boundary objects on group collaboration in construction project teams." Proc., International ACM Siggroup Conference on Supporting Group Work, 125-128.

Pinto, J. K., Slevin, D. P., and English, B. (2009). "Trust in projects: An empirical assessment of owner/contractor relationships." International Journal of Project Management, 27(6), 638-648.

Pistor, K., Raiser, M., and Gelfer, S. (2000). "Law and Finance in Transition Economies." Economics of Transition, 8(2), 325-368.

Podsakoff, P. M., MacKenzie, S. B., Lee, J.-Y., and Podsakoff, N. P. (2003). "Common method biases in behavioral research: a critical review of the literature and recommended remedies." Journal of applied psychology, 88(5), 879.

Poppo, L., and Zenger, T. (2002). "Do formal contracts and relational governance function as substitutes or complements?" Strategic management journal, 23(8), 707-725.

Rahman, M., and Alhassan, A. (2012). "A contractor's perception on early contractor involvement." Built Environment Project \& Asset Management, 2(2), 217-233.

Sallinen, L., Ruuska, I., and Ahola, T. (2013). "How governmental stakeholders influence large projects: the case of nuclear power plant projects." International Journal of Managing Projects in Business, 6(1), 51-68.

Schepker, D. J., Oh, W. Y., Martynov, A., and Poppo, L. (2014). "The many futures of contracts : moving beyond structure and safeguarding to coordination and adaptation." Journal of Management, 40(1), 193-225.

Schilke, O., and Cook, K. S. (2015). "Sources of alliance partner trustworthiness: Integrating calculative and relational perspectives." Strategic Management Journal, 36(2), 276-297.

Sezen, B., and Yilmaz, C. (2007). "Relative effects of dependence and trust on flexibility, information exchange, and solidarity in marketing channels." Journal of Business \& Industrial Marketing, 22(1), 41-51.

Shiu, E., Jiang, Z., and Zaefarian, G. (2014). "Antecedents of behavioural commitment in interorganizational relationships: a field study of the UK construction industry." Construction Management and Economics, 32(9), 888-903.

Singh, A., and Teng, J. T. (2016). "Enhancing supply chain outcomes through Information Technology and Trust." Comput. Human Behav., 54, 290-300.

Stinchcombe, A. L., and Heimer, C. A. (1985). Organization theory and project management : administering uncertainty in Norwegian offshore oil, Oxford University Press, USA.

Tanriverdi, H., Konana, P., and Ge, L. (2007). "The Choice of Sourcing Mechanisms for Business Processes." Information Systems Research, 18(3), 280-299.

Tatikonda, M. V., and Montoya-Weiss, M. M. (2001). "Integrating Operations and Marketing Perspectives of Product Innovation: The Influence of Organizational Process Factors and Capabilities on Development Performance." Management Science, 47(1), 151-172.

Tatikonda, M. V., and Rosenthal, S. R. (2000). "Technology novelty, project complexity, and product development project execution success: a deeper look at task uncertainty in product innovation." IEEE Transactions on Engineering Management, 47(1), 74-87.

Wang, L., Yeung, J. H. Y., and Zhang, M. (2011). "The impact of trust and contract on innovation 
performance: The moderating role of environmental uncertainty." International Journal of Production Economics, 134(1), 114-122.

Wang, Q., Bradford, K., Xu, J., and Weitz, B. (2008). "Creativity in buyer-seller relationships: The role of governance 2 ." International Journal of Research in Marketing, 25(2), 109-118.

Weitz, B. A., and Jap, S. D. (1995). "Relationship marketing and distribution channels." Journal of the Academy of Marketing Science, 23(4), 305-320.

Williamson, O. E. (1985). The economic institutions of capitalism: Firms, markets, relational contracting, Free Press, New York.

Winch, G. (1989). "The construction firm and the construction project: a transaction cost approach." Construction Management and Economics, 7(4), 331-345.

Wu, G., Zhao, X., and Zuo, J. (2017a). "Relationship between Project's Added Value and the TrustConflict Interaction among Project Teams." Journal of Management in Engineering, 33(4):04017011.

Wu, A., Wang, Z., and Chen, S. (2017b). "Impact of specific investments, governance mechanisms and behaviors on the performance of cooperative innovation projects." International Journal of Project Management, 35(3), 504-515.

Wuyts, S., and Geyskens, I. (2005). "The formation of buyer-supplier relationships: detailed contract drafting and close partner selection." Journal of Marketing, 69(4), 103-117.

Xin, K. R., and Pearce, J. L. (1996). "Guanxi: Connections as Substitutes for Formal Institutional Support." Academy of Management Journal, 39(6), 1641-1658.

Xue, J., Yuan, H., and Shi, B. (2016). "Impact of contextual variables on effectiveness of partnership governance mechanisms in megaprojects: Case of Guanxi." Journal of Management in Engineering, 33(1), 04016034.

Yan, T., and Dooley, K. J. (2013). "Communication intensity, goal congruence, and uncertainty in buyer"Csupplier new product development." Journal of Operations Management, 31(7), 523 542.

Yang, J., Shen, G. Q., Ho, M., Drew, D. S., and Xue, X. (2011). "Stakeholder management in construction: An empirical study to address research gaps in previous studies." International Journal of Project Management, 29(7), 900-910.

Zhai, Z., Ahola, T., Le, Y., Xie, J. X. (2017). "Governmental Governance of Megaprojects: The Case of EXPO 2010 Shanghai." Project Management Journal, 48(1), 37-50.

Zhang, Q., and Zhou, K. Z. (2013). "Governing interfirm knowledge transfer in the Chinese market: The interplay of formal and informal mechanisms." Industrial Marketing Management, 42(5), 783 791.

Zhang, S. B., Fu, Y. F., Gao, Y., and Zheng, X. D. (2016). "Influence of trust and contract on dispute negotiation behavioral strategy in construction subcontracting." Journal of Management in Engineering, 32(4), 04016001.

Zhang, Z., Wan, D., Jia, M., and Gu, L. (2009). "Prior ties, shared values and cooperation in publicprivate partnerships." Management and Organization Review, 5(3), 353-374.

Zheng, X., Lu, Y., Le, Y., Li, Y., and Fang, J. (2017). Formation of Interorganizational Relational Behavior in Megaprojects: Perspective of the Extended Theory of Planned Behavior. Journal of Management in Engineering, 34(1), 04017052.

Zhou, X., Li, Q., Zhao, W., and Cai, H. (2003). "Embeddedness and contractual relationships in China's transitional economy." Am. Sociol. Rev., 75-102. 

in a Chinese Marketing Channel." Journal of Marketing Channels, 15(2-3), 185-210. 


\section{List of tables}

Table 1. Illustrations of main dimensions of key literature on governance mechanisms

Table 2. Measurements of constructs

Table 3. Demographics of surveyed projects and respondents

Table 4. Descriptive statistics and correlations

Table 5. Factor loading of each items, AVE and CR of each construct

Table 6. Standardized regression results 
TABLE 1. Illustrations of main dimensions of key literature on governance mechanisms

Type of formal governance

Type of informal governance

Key literature

mechanism

mechanism

- Ex ante contracts

- Trust

Zhang and Zhou (2013)

- Ex post control

- Formal contract

- Relational norms,

Arranz and Arroyabe

- Trust

(2012)

- Explicit contracts

- Social norms

Burkert et al. (2012)

- Relationship-specific

- Trust investments

- Contracts

- Structural mechanisms

- Trust

- Relational mechanism

Chen et al. (2013) (contracts)

- Administrative mechanism (collaboration and information Jayaraman et al. (2013) (effective allocation and demarcation of responsibilities)

- Contract

- Trust

Malhotra and

- Contractual safeguards

- Trustworthiness

Lumineau (2011)

Schilke and Cook

(2015)

- Contract

- Trust

- Formal control

- Social control

Jiang et al. (2013)

- Administrative control, through

- A dominant power position

Jin et al. (2014) explicit contractual agreements;

- Social/relational control

Caniëls and Gelderman a dominant power position

- Incentives,

- Authority

- Trust

- Contract

- Trust

Olsen et al. (2005)

- Power

- Formal contracts

- Brokered access,

- Shared goals,

- Trust

None

- Relational governance

Wang et al. (2008)

Li et al. (2010) (institutional support from the

Chi and Javernick government)

None

- Governmental governance

Zhai (2017) (institutional support from the government) 
TABLE 2. Measurements of constructs

\begin{tabular}{|c|c|c|}
\hline Constructs & Description of measurement items & Key sources \\
\hline $\begin{array}{l}\text { Contractual term } \\
\text { specificity (TS) }\end{array}$ & $\begin{array}{l}\text { TS1 - Governed by written contracts } \\
\text { primarily; } \\
\text { TS2 - Detailed obligations and rights; } \\
\text { TS3 - Detailed rewards and punishments. }\end{array}$ & $\begin{array}{l}\text { Fryxell et al. } \\
(2002) ; \\
\text { Jap and Ganesan } \\
(2000)\end{array}$ \\
\hline $\begin{array}{l}\text { Contractual } \\
\text { contingency } \\
\text { adaptability (CA) }\end{array}$ & $\begin{array}{l}\text { CA1 - Detailed approaches for unexpected } \\
\text { situations; } \\
\text { CA2 - Detailed approaches for conflicts. }\end{array}$ & $\begin{array}{l}\text { Goo et al. (2009); } \\
\text { Luo (2002) }\end{array}$ \\
\hline Trust (TR) & $\begin{array}{l}\text { TR1 - Trustworthy of other participants; } \\
\text { TR2 - Ability of other participants to perform } \\
\text { tasks; } \\
\text { TR3 - Keeping promises; } \\
\text { TR4 - Good reputation of other participants; } \\
\text { TR5 - Believing provided information of other } \\
\text { participants. }\end{array}$ & Lu et al. (2015) \\
\hline $\begin{array}{l}\text { Institutional } \\
\text { support (IS) }\end{array}$ & $\begin{array}{l}\text { IS } 1 \text { - Building harmonious relationship among } \\
\text { multiple stakeholders by the government; } \\
\text { IS } 2 \text { - Implementing policies and programs by } \\
\text { the government. }\end{array}$ & $\begin{array}{l}\text { Li and Atuahene- } \\
\text { Gima (2001) }\end{array}$ \\
\hline $\begin{array}{l}\text { Relational } \\
\text { behavior (RB) }\end{array}$ & $\begin{array}{l}\text { 1) Solidarity (RBS) } \\
\text { RBS1 - Addressing problems jointly; } \\
\text { RBS2 - Helping others; } \\
\text { RBS3 - Committing to improving project } \\
\text { relationship. } \\
\text { 2) Flexibility (RBF) } \\
\text { RBF1 - Flexible to changes; } \\
\text { RBF2 - Flexible to conflicts. } \\
\text { 3) Information sharing (RBI) } \\
\text { RBI1 - Providing proprietary information; } \\
\text { RBI2 - Updating information to other } \\
\text { participants; } \\
\text { RBI3 - Providing information frequently. }\end{array}$ & $\begin{array}{l}\text { Hoppner and } \\
\text { Griffith (2011) }\end{array}$ \\
\hline $\begin{array}{l}\text { Team performance } \\
\text { (TP) }\end{array}$ & $\begin{array}{l}\text { TP1 - Satisfied with the time performance; } \\
\text { TP2 - Satisfied with the quality performance; } \\
\text { TP } 3 \text { - Satisfied with the cost performance; } \\
\text { TP4 - Building long-term partnership; } \\
\text { TP5 - Collaborating joint projects in the } \\
\text { future. }\end{array}$ & Lu et al. (2015) \\
\hline $\begin{array}{l}\text { Project uncertainty } \\
\text { (PU) }\end{array}$ & $\begin{array}{l}\text { PU1 - Environmental uncertainty; } \\
\text { PU2 - Task uncertainty; } \\
\text { PU3 - Technological innovation. }\end{array}$ & $\begin{array}{l}\text { Yan and Dooley } \\
\text { (2013) }\end{array}$ \\
\hline
\end{tabular}


TABLE 3. Demographics of surveyed projects and respondents

\begin{tabular}{|c|c|c|c|}
\hline Variable & Category & Number & Percentage \\
\hline \multirow{2}{*}{$\begin{array}{l}\text { Types of respondent } \\
\text { firms }\end{array}$} & Designer & 106 & $52.48 \%$ \\
\hline & Contractor & 96 & $47.52 \%$ \\
\hline \multirow{3}{*}{$\begin{array}{l}\text { Positions of } \\
\text { respondents }\end{array}$} & Project directors & 36 & $17.82 \%$ \\
\hline & $\begin{array}{l}\text { Project/team } \\
\text { managers }\end{array}$ & 77 & $38.12 \%$ \\
\hline & $\begin{array}{l}\text { Department/operation } \\
\text { managers }\end{array}$ & 89 & $44.06 \%$ \\
\hline \multirow[t]{10}{*}{ Project type } & Transportation hub & 99 & $49.01 \%$ \\
\hline & Road & 12 & $5.94 \%$ \\
\hline & Bridge & 10 & $4.95 \%$ \\
\hline & Tunnel & 9 & $4.46 \%$ \\
\hline & Railway & 6 & $2.97 \%$ \\
\hline & Highway & 2 & $0.99 \%$ \\
\hline & Airport & 13 & $6.44 \%$ \\
\hline & Skyscraper & 11 & $5.45 \%$ \\
\hline & Dam & 32 & $15.84 \%$ \\
\hline & $\begin{array}{l}\text { Public building (such } \\
\text { as event facilities) }\end{array}$ & 8 & $3.96 \%$ \\
\hline \multirow[t]{6}{*}{ Project location } & North China & 11 & $5.45 \%$ \\
\hline & Northeast China & 1 & $0.50 \%$ \\
\hline & East China & 98 & $48.51 \%$ \\
\hline & South Central China & 72 & $35.64 \%$ \\
\hline & Southwest China & 17 & $8.42 \%$ \\
\hline & Northwest China & 3 & $1.49 \%$ \\
\hline
\end{tabular}


TABLE 4. Descriptive statistics and correlations

\begin{tabular}{|c|c|c|c|c|c|c|c|c|c|c|}
\hline Variables & 1 & 2 & 3 & 4 & 5 & 6 & 7 & 8 & 9 & 10 \\
\hline $\begin{array}{l}\text { 1. Contractual term } \\
\text { specificity }\end{array}$ & 1 & & & & & & & & & \\
\hline $\begin{array}{l}\text { 2. Contractual } \\
\text { contingency } \\
\text { adaptability }\end{array}$ & $0.70^{* *}$ & 1 & & & & & & & & \\
\hline 3. Trust & $0.49^{* *}$ & $0.48^{* *}$ & 1 & & & & & & & \\
\hline 4. Institutional support & $0.30^{* *}$ & $0.17^{*}$ & $0.23^{* *}$ & 1 & & & & & & \\
\hline 5. Relational behavior & $0.45^{* *}$ & $0.35^{* *}$ & $0.48^{* *}$ & $0.35^{* *}$ & 1 & & & & & \\
\hline 6. Project uncertainty & $0.15^{*}$ & 0.10 & $0.31^{* *}$ & 0.14 & $0.16^{*}$ & 1 & & & & \\
\hline 7. Team performance & $0.27^{* *}$ & $0.22^{* *}$ & $0.35^{* *}$ & $0.27^{* *}$ & $0.57^{* *}$ & -0.06 & 1 & & & \\
\hline 8. Project duration & 0.01 & -0.00 & $0.21^{* *}$ & -0.08 & 0.06 & -0.01 & 0.11 & 1 & & \\
\hline $\begin{array}{l}\text { 9. Project delivery } \\
\text { method }\end{array}$ & $0.14^{*}$ & 0.06 & 0.00 & 0.01 & -0.05 & -0.02 & $-0.15^{*}$ & -0.05 & 1 & \\
\hline $\begin{array}{l}\text { 10. Prior collaborative } \\
\text { experience }\end{array}$ & 0.11 & 0.06 & 0.03 & $0.17^{*}$ & 0.06 & 0.03 & $0.15^{*}$ & $0.18^{*}$ & 0.10 & 1 \\
\hline Mean & 4.04 & 3.78 & 3.91 & 4.16 & 3.83 & 3.55 & 3.87 & 1.53 & 1.29 & 0.71 \\
\hline Standard & 0.53 & 0.68 & 0.52 & 0.57 & 0.36 & 0.64 & 0.42 & 0.50 & 0.79 & 0.45 \\
\hline Deviation(S.D.) & & & & & & & & & & \\
\hline
\end{tabular}

Note: Sample size $=202$.

*Significance at $p<0.05$ level.

${ }^{* *}$ Significance at $p<0.01$ level. 
TABLE 5. Factor loading of each items, AVE and CR of each construct

\begin{tabular}{|c|c|c|c|c|}
\hline Construct/item & Loading & $t$-value & AVE & $\mathrm{CR}$ \\
\hline $\begin{array}{l}\text { Contractual term } \\
\text { specificity (TS) }\end{array}$ & & & 0.66 & 0.85 \\
\hline TS1 & 0.84 & 27.71 & & \\
\hline TS2 & 0.84 & 27.70 & & \\
\hline TS3 & 0.74 & 14.87 & & \\
\hline $\begin{array}{l}\text { Contractual contingency } \\
\text { adaptability (CA) }\end{array}$ & & & 0.84 & 0.91 \\
\hline CA1 & 0.94 & 63.46 & & \\
\hline $\mathrm{CA} 2$ & 0.89 & 30.62 & & \\
\hline Trust (TR) & & & 0.53 & 0.85 \\
\hline TR1 & 0.69 & 13.34 & & \\
\hline TR2 & 0.71 & 16.17 & & \\
\hline TR3 & 0.76 & 20.84 & & \\
\hline TR4 & 0.66 & 12.19 & & \\
\hline TR5 & 0.82 & 32.46 & & \\
\hline Institutional support (IS) & & & 0.71 & 0.83 \\
\hline IS1 & 0.88 & 20.11 & & \\
\hline IS2 & 0.80 & 12.31 & & \\
\hline Solidarity (RBS) & & & 0.65 & 0.85 \\
\hline RBS1 & 0.85 & 35.60 & & \\
\hline RBS2 & 0.71 & 15.05 & & \\
\hline RBS3 & 0.85 & 42.29 & & \\
\hline Flexibility (RBF) & & & 0.86 & 0.92 \\
\hline RBF1 & 0.92 & 67.04 & & \\
\hline RBF2 & 0.93 & 96.60 & & \\
\hline $\begin{array}{l}\text { Information exchange } \\
\text { (RBI) }\end{array}$ & & & 0.66 & 0.85 \\
\hline RBI1 & 0.76 & 19.87 & & \\
\hline RBI2 & 0.87 & 43.34 & & \\
\hline RBI3 & 0.81 & 23.68 & & \\
\hline Team performance $(\mathrm{TP})$ & & & 0.61 & 0.88 \\
\hline TP1 & 0.84 & 35.07 & & \\
\hline TP2 & 0.78 & 25.40 & & \\
\hline TP3 & 0.73 & 21.78 & & \\
\hline TP4 & 0.79 & 24.93 & & \\
\hline TP5 & 0.75 & 20.48 & & \\
\hline
\end{tabular}




\begin{tabular}{ccccc}
\hline \hline Construct/item & Loading & $t$-value & AVE & CR \\
\hline Project Uncertainty (PU) & & & 0.60 & 0.82 \\
PU1 & 0.68 & 3.10 & & \\
PU2 & 0.85 & 4.58 & & \\
PU3 & 0.78 & 4.12 & & \\
\hline \hline
\end{tabular}

Note: $\mathrm{CR}=$ composite reliability; $\mathrm{AVE}=$ average variance extracted. 
TABLE 6. Standardized regression results a

\begin{tabular}{|c|c|c|c|c|}
\hline & Model $1{ }^{\mathrm{b}}$ & Model 2 & Model 3 & Model 4 \\
\hline & $\beta$ & $\beta$ & $\beta$ & $\beta$ \\
\hline \multicolumn{5}{|l|}{ Control variables } \\
\hline Project duration & 0.05 & 0.00 & 0.01 & \\
\hline Project delivery method & -0.05 & -0.09 & -0.09 & \\
\hline Prior collaborative experience & 0.06 & -0.01 & -0.01 & \\
\hline \multicolumn{5}{|l|}{ Independent variables } \\
\hline Contractual term specificity (XI) & & $0.25^{* *}$ & $0.23^{* *}$ & \\
\hline Contractual contingency adaptability (X2) & & -0.01 & -0.01 & \\
\hline Trust (X3) & & $0.31^{* * *}$ & $0.29^{* * *}$ & \\
\hline Institutional support (X4) & & $0.20^{* * *}$ & $0.19^{* * *}$ & \\
\hline Relational behavior & & & & $0.57^{* * *}$ \\
\hline \multicolumn{5}{|l|}{ Moderating variable } \\
\hline Project uncertainty (X5) & & -0.01 & 0.04 & \\
\hline \multicolumn{5}{|l|}{ Interaction terms } \\
\hline$X 1 * X 3$ & & & $0.19^{*}$ & \\
\hline$X 2 * X 3$ & & & -0.09 & \\
\hline$X 1 * X 5$ & & & $-0.35^{* * *}$ & \\
\hline$X 2 * X 5$ & & & $0.18^{+}$ & \\
\hline$X 3 * X 5$ & & & $0.13^{+}$ & \\
\hline$R^{2}$ & 0.01 & 0.33 & 0.38 & 0.32 \\
\hline$F$-value & 0.57 & $11.95^{* * *}$ & $8.99^{* * *}$ & $93.54^{* * *}$ \\
\hline$\Delta R^{2}$ & & $0.32^{* * *}$ & $0.05^{* *}$ & \\
\hline
\end{tabular}

Note: $\mathrm{N}=202$

${ }^{* * *} p<0.001$

${ }^{* *} p<0.01$

${ }^{*} p<0.05$;

${ }^{+} p<0.1$ (two-tailed).

${ }^{a}$ The entries in the Table are standardized path coefficients.

${ }^{\mathrm{b}}$ The dependent variable of Model 1 to Model 3 is relational behavior while the dependent variable of Model 4 is team performance. 


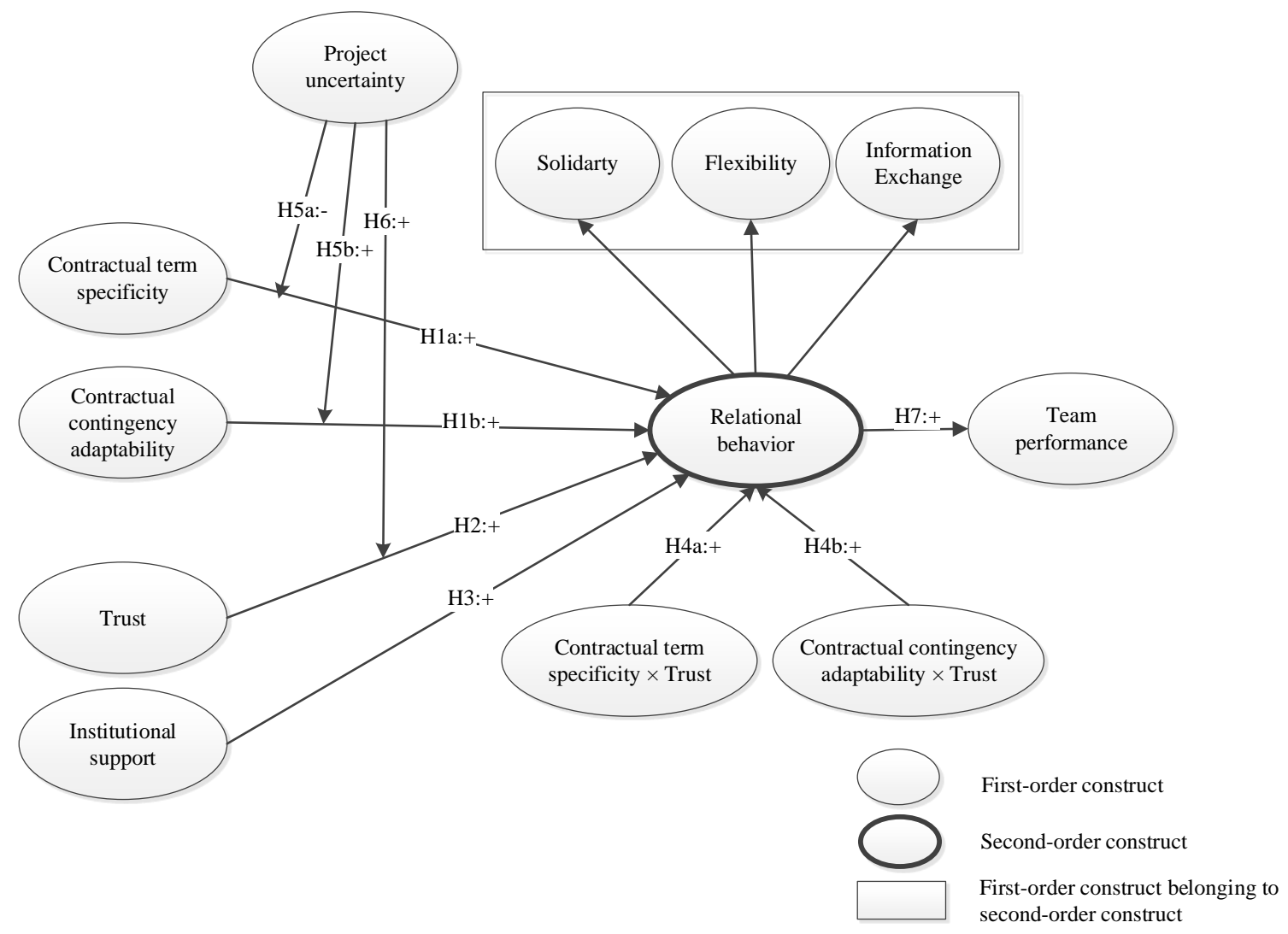

Fig.1. Concept model of the effect of governance mechanisms on relational behavior. 

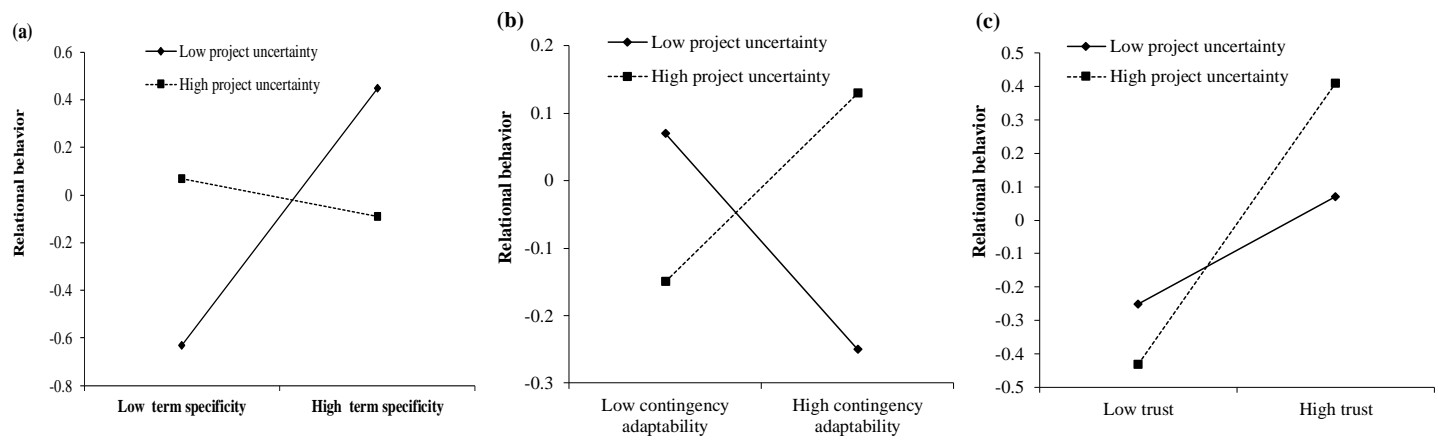

Fig.2. Moderating effects of project uncertainty on the relationship (a) between contractual term specificity and relational behavior; (b) between contractual contingency adaptability and relational behavior; (c) between trust and relational behavior.

Notes: Low and high project uncertainty are equivalent to one standard deviation below and above the means of project uncertainty. 